\title{
MODERN ARABIC LITERATURE AND ISLAMIST DISCOURSE "DO NOT BE COOLNESS, DO NOT FLUTTER SAFETY"
}

\author{
Reuven Snir
}

HAIFA

\begin{abstract}
With the rise of Islam, Arab civilization was given a defined ideological and cultural framework within which it could develop. Islam, as a system of symbols, represents the most significant factor in the explanation of Arab cultural, intellectual, and literary history since the seventh century. Arabic literature was never wholly a religious one, but since the revelation of the Qur ${ }^{\circ} \bar{n}$, the various activities in the literary system generally occurred within the borders defined by Islam and were guided by a cultural heritage that seemed nearly as sacred as the religious law. Islam and, more specifically, the Qur ${ }^{\circ} \bar{n}$, was also predominant in consolidating principles that ensured, according to most Arab intellectuals in the twentieth century, that modern Arabic literature could only be a direct extension of the classical literature. The dominance of Islamist discourse in the literary system during the last century was reflected through censorship and banning of books for religious considerations and for the harm they might do to public morality. Nevertheless, Arabic literature witnessed during the second half of the previous century a strong trend towards separation from its strict Islamic moorings in order to follow its course as a completely secularized literature. This trend has found its manifestation in both the interrelations of the literary system with other extra-literary systems as well as on the level of the texts themselves. (The term "Islamist" is used here to refer to the cultural activities and the discourse of the religious circles; conversely, the terms "Muslim" or "Islamic" are applied to general religious and traditional cultural phenomena).
\end{abstract}

\section{Introduction}

The nature of Arabic literature since the seventh century A.D. was largely determined by its interaction with Islam, the religion that the overwhelming majority of Arabs adhere to. With the rise of Islam, Arabic literature, as Arab civilization in general, ${ }^{1}$ was given a defined

\footnotetext{
${ }^{1}$ Not seldom Arab intellectuals refer to Arab civilization prior to Islam as deficient; see, for example, Muhammad Jalāl Kishk, al-Ghazw al-fikrī (Cairo:
} 
ideological and cultural framework within which it could develop. With time it admitted, as did Islamic civilization, such contributions from outside as would help it to keep its identity under changed conditions and at the same time broaden "its base beyond the limitations inherent in the Koranic text." This meant, as Gustave E. von Grunebaum said, that "while Islam for many a century continued liberal in accepting information, techniques, objects, and customs from all quarters, it was careful to eliminate or neutralize any element endangering its religious foundation, and it endeavored consistently to obscure the foreign character of important borrowings and to reject what could not be thus adjusted to its style of thinking and feeling." 2

Islam and, more specifically, the Qur ${ }^{\circ} \bar{n}$, were also prominent in consolidating the principles that ensured, at least according to some Arab intellectuals, that modern Arabic literature could only be a direct extension of classical literature. Thus the way we view the relationship between classical and modern literature is essential to our understanding of the nature of the Arabic literary system in the twentieth century and its relationship with the religious discourse. ${ }^{3}$ The question is whether modern literature is an extension of classical literature or a new creation that has hardly any relationship at all with its medieval predecessor. It is no coincidence that Arab, especially Muslim, scholars tend to the first view, whereas the second view has been mainly adopted by Western scholars.

al-Dār al-Qawmiyya li-1-Ṭibāc a wa-l-Nashr, 1966), 18-19:

عندما نتحدث عن حضارتنا نعني الإسلام، حتى ولو كان لنا امتداد عربي قبل الإسلام، ورغم اعتزازنا بأطلال

الحضارة الفرعونية أو الفينيقية، وبذلك الشعب الذي عاش على نفس الأرض من آلاف السنين، إلا أن الأمر لا

يخرج عن دائرة الاعتزاز . . . لم يكن للعرب حضارة متكاملة إلا بظهور الإسلام، ولم تمتحن حضارتنا إلا بعد

أن خرجت من الجزيرة إلى ميدان التطبيق بين كافّة الأجناس البشرية المعروفة، واجتازت التجربة بذجاح.

2 Gustave E. von Grunebaum, Medieval Islam (Chicago: The University of Chicago Press, 1953), 321. Cf. idem, "The Spirit of Islam as Shown in its Literature," Studia islamica 1 (1953), 101-19.

3 On the system theory and for a particular model for the study of modern Arabic literature, see R. Snir, "Synchronic and Diachronic Dynamics in Modern Arabic Literature," in Studies in Canonical and Popular Arabic Literature, ed. S. Ballas and R. Snir (Toronto: York Press, 1998), 87-121; idem, Modern Arabic Literature: A Functional Dynamic Historical Model (Toronto: York Press, 2001). 
In his article "Arabic Literature between its Past and Future," which opened in October 1945 the first issue of his journal al-Kātib al-mișrī, Ṭāhā Husayn (1889-1973) asserts the continuity of Arabic literature. Unlike Greek and Latin literature, which have no direct contemporary extension, modern Arabic literature, according to Husayn, is a direct linear extension of classical literature:

The historical existence of Arabic literature has never been cut off, and it seems that it will never be cut off. The connection between this literature and contemporary generations in the lands of the Arab East, from the Persian Gulf to the Atlantic Ocean, and in various Arab lands here and there, is still strong and fertile, like the connection between Arabic literature and the Arab nation during the period of al-Mutannabī and Abū al- ${ }^{c} \mathrm{Ala} \bar{a}^{\supset}$.... Arabic literature is very traditional and at the same time very modern. Its ancient past has been directly mingled with its modern present without any break or bend. ... Our Arabic literature is a living being and resembles, more than anything else, a huge tree, the roots of which have been consolidated and extended into the depths of earth, while its branches have risen and spread out in space. The water of life is still ample and running in its steady roots and its high branches. ... Our Arabic literature is definitely a traditional one, possessing an old Arab-Bedouin character that it never relinquished, nor will it ever do so. ... The way in which we see things might change as ages, regions and circumstances change. But our way of portraying things, even if it takes different shapes, will always go back to a set of traditional principles that cannot possibly be avoided, because such avoidance means killing this literature and breaking the connection between it and the new time, as well as deterring it from the road of the continuous life of the living literatures into the road of cut-off life that the Greek and Latin literatures took. ${ }^{5}$

This direct extension of classical into modern literature has been guaranteed, according to Husayn, by the continuous equilibrium Arabic literature retained until modern times between the factors of continuity and change:

The revival of ancient Arabic literature ${ }^{6}$ was, and still is, turning modern Arab minds towards the past, highlighting elements of stability and steadfastness. On the other hand, the contact with modern European literature has been pushing

${ }^{4}$ Ṭāhā Ḥusayn, "al-Adab al- ${ }^{c}$ arabī bayna amsihi wa-ghadihi," al-Kātib almișrī 1,1 (October 1945): 4-27; The article was also incorporated in Ṭāhā Ḥusayn, Alwān (Cairo: Dār al-Macārif, n.d. [1958]), 5-32.

5 Husayn 1945, 10-11; Husayn n.d. [1958], 11-13 (emphasis added, R.S.).

${ }^{6}$ That is, through the editing and disseminating of classical texts since the mid-nineteenth century. 
Arabic literature in a different direction, stressing elements of mobility and change. It is surprising that the Arab mind has maintained its equilibrium in spite of this fierce conflict. Indeed, it has benefited from it immensely. ${ }^{7}$

By preserving some traditional principles to ensure its distinctive identity and at the same time incorporating a variety of innovations both in form and content, Arabic literature, according to Ṭāhā Husayn, has proved its vitality through the ages. ${ }^{8}$

The contrary view we find neatly summarized by Hamilton Gibb, one of the first Western scholars to study modern Arabic literature systematically, ${ }^{9}$ in an article published in 1928:

It may be asked ... by what right Arabic literature is called a young literature. To all appearances, it is entitled to claim a history of thirteen centuries, a longer period of continuous literary activity than any living European language can boast. But beneath the apparent linguistic continuity, Arabic literature is undergoing an evolution comparable, in some respects, to the substitution of Patristic for Classical Greek literature and idiom. Neo-Arabic literature is only to a limited extent the heir of the old "classical" Arabic literature, and even shows a tendency to repudiate its inheritance entirely. Its leaders are, for the most part, men who have drunk from other springs and look at the world with different eyes. Yet the past still plays a part in their intellectual background, and there is a section among them upon whom that past retains a hold scarcely shaken by newer influences. For many decades, the partisans of the "old" and the "new" have engaged in a struggle for the soul of the Arabic world, a struggle in which the victory of one side over the other is even yet not assured. The protagonists are (to classify them roughly for practical purposes) the European-educated classes of Egyptians and Syrians on the one hand, and those in Egypt and the less advanced Arabic lands whose education has followed traditional lines, on the other. Whatever the ultimate result may be, however, there can be no question that the conflict has torn the Arabic world from its ancient moorings, and that the contemporary literature of Egypt and Syria breathes, in its more recent developments, a spirit foreign to the old traditions. ${ }^{10}$

\footnotetext{
7 Husayn 1945, 17; Husayn n.d. [1958], 20.

${ }^{8}$ Cf. David Semah, Four Egyptian Literary Critics (Leiden: Brill, 1974), 122.

${ }^{9}$ See "Studies in Contemporary Arabic Literature," in Hamilton A. R. Gibb, Studies on the Civilization of Islam (London: Routledge \& Kegan, 1962), 245319 , which is based upon a series of articles first published in Bulletin of the School of Oriental Studies (BSOAS 4,4 [1928]: 745-60; 5,2 [1929]: 311-22; 5,3 [1929]: 445-66; 7,1 [1933]: 1-22).

10 Gibb 1962, 246-47 (emphasis added, R.S.).
} 
At least from one aspect, that is, the Islamic framework, modern Arabic literature produced during most of the twentieth century was largely perceived as an extension of the classical one. As numerous episodes attest, ${ }^{11}$ most modern Arabic literary production adhered to the principles of the Islamic discourse, and Arabic literature, including that written in the modern period, has even been described as Islamic literature. ${ }^{12}$ According to this view Islam, as a system of symbols, represents the most significant factor in the explanation of Arab cultural, intellectual, and literary history. It is an ideological generalizing approach that sees Arabic literature as a cultural product of Islam, and at the same time overlooks the interactions between literary texts and the discursive contexts within which they were produced and the diverse literary and social movements that emerged over time. The dominance of Islamic discourse in the literary system was also reflected through censorship of books and their being banned for religious considerations and for the harm they might do to public morality. ${ }^{13}$

${ }^{11}$ See, for example, Shimon Ballas, al-Adab al- ${ }^{c}$ arabì wa-l-tahdìth al-fikrī (Cologne: Manshūrāt al-Jamal, 1993).

12 E.g., Najib Ullah, Islamic Literature (New York: Washington Square Press, 1963), 172-211; James Kritzeck, Anthology of Islamic Literature (New York: Holt, Rinehart \& Winston, 1964); A Rosary of Islamic Readings, ed. G. Allana (Karachi; Rawalpindi: National Publishing House, 1973).

${ }^{13}$ On censorship in the Arab world, see Kanan Makiya, Cruelty and Silence: War, Tyranny, Uprising and the Arab World (New York \& London: W. W. Norton, 1993), 281; Encyclopedia of Arabic Literature, ed. Julie Scott Meisami and Paul Starkey (London and New York: Routledge), 1: 171-72; Mass Media, Politics, and Society in the Middle East, ed. Kai Hafez (Cresskill, NJ: Hampton Press, 2001), 10. The journal al-Āda b published a series of dossiers about the intricacies of censorship and cultural production in the Arab world. The first of them, in vol. 50, 7-8 (July-August 2002), presents the case of censorship in Syria. The second, in vol. 50, 11-12 (November-December 2002), concerns Egypt. The third, in vol. 51, 9-10 (October-November 2003), deals with Morocco. On censorship of the press in the Arab world in general, see Ami Ayalon, The Press in the Arab Middle East (New York \& Oxford: Oxford University Press, 1995), 79-80, 115-17 (Egypt), 84-87, 121-22 (Syria); 90-91 (Lebanon); 98-100 (Palestine). See also William A. Rugh, The Arab Press: News Media and Political Process in the Arab World (Syracuse, NY: Syracuse University Press, 1979), index. For the history of censorship in Islamic societies, see Trevor Mostyn, A History of Censorship in Islamic Societies (London: Saqi Books, 2001). On freedom of speech in Egypt under ${ }^{\mathrm{C}} \mathrm{Abd}$ al-Nāṣir and alSādāt, in addition to thirteen case studies on censorship of prose works, see 


\section{Censorship of Scholarly and Literary Texts}

Cases of censorship on moral grounds have been very frequent and publishers have generally avoided publishing classical works considered as harmful to public morality without censoring them. For example, because it is sometimes considered as belonging to pornographic literature, ${ }^{14}$ al-Rawd al- ${ }^{c}$ ătir fi nuzhat al-khātir (The perfumed garden in the promenade of the mind) by Muhammad b. Muhammad al-Nafzāwī from the 15 the century has never been published unabridged by any major publisher in the Arab world. The only printed versions existing are popular editions or partial ones such as that by Maktabat Usāma in Damascus, which also includes several articles about the book and its reception. ${ }^{15}$ An unabridged edition was published by the London based publisher Riyād al-Rayyis. ${ }^{16}$

One famous instance of censorship on moral grounds in Lebanon was the case of Laylā Baclabakkī (b. 1936) and her collection of short stories Safinat hanān ilä al-qamar (A space ship of tenderness to the moon) first published in 1963.17 The public prosecutor of the Court of Appeals,

Marina Stagh, The Limits of Freedom of Speech: Prose Literature and Prose Writers in Egypt under Nasser and Sadat (Stockholm: Almqvist \& Wiksell International, 1993). In the first five months of 1989, for example, fifty-five books were banned in Egypt (al-Ahālì, [7 June 1989], 11). Censorship has even included classical books, such those of the Sūfins, e.g., Annemarie Schimmel, As Through a Veil, Mystical Poetry in Islam (New York: Columbia University Press, 1982), 39; Ghālī Shukrī, al-Khurūj c alā al-nașs: Tahaddiyāt al-thaqāfa wa-l-dìmuqrātiyya (Cairo: Sīnā li-l-Nashr, 1994), 68, n. 19. On censorship of theatrical productions in Egypt between 1923 and 1988, see Sayyid ${ }^{\mathrm{c}} \mathrm{Al} \overline{\mathrm{I}} \mathrm{Isma} \overline{\mathrm{c}}^{\mathrm{1}} \mathrm{l}$, al-Raqāba wa-l-masrah al-marfüd 1923-1988 (Cairo: al-Hay a al-Mișriyya al${ }^{\mathrm{c}}$ Āmma li-1-Kitāb, 1997). On the theoretical dimensions of censorship in Muslim societies, see Mohammed Arkoun, The Unthought in Contemporary Islamic Thought (London: Saqi Books \& The Institute of Ismaili Studies, 2002), esp. 936.

${ }^{14}$ In Arabic such literature is variously called adab al-jins (sex literature), adab al-ithāra al-jinsiyya (literature of sexual stimulation), al-adab al-khalāc $\bar{\imath}$ (shameless literature), al-adab al-makshūf (brazen literature), al-adab al-fāhish (dirty literature) or al-adab al-ibāḥ̄ (licentious literature).

15 See Muhammad b. Muhammad al-Nafzāwī, Shahādāt wa-mukhtārāt min al-Rawd al- ${ }^{c} \bar{a} t i r$ fì nuzhat al-khātir, ed. Hānī al-Khayyir (Damascus: Maktabat Usāma, 1983).

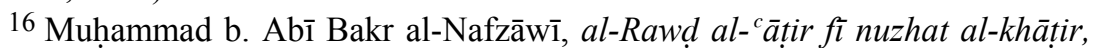
ed. Jamāl Jumca (London: Riyāḍ al-Rayyis, 1990).

${ }^{17}$ Laylā Ba ${ }^{c}$ labakkī, Safinat hanān ilā al-qamar (Beirut: al-Maktab al-Tijārī 
$\mathrm{Sa}^{\mathrm{c}} \overline{\mathrm{i}} \mathrm{d}$ al-Barjawī, summoned the writer, in accordance with item 532 of the Lebanese criminal law, and accused her of harming public morality demanding a prison sentence of one to six months plus an apparently symbolic fine of ten to one hundred liras. At the same time members of the Beirut vice squad confiscated the remaining copies of the book from the bookstores. On 23 August 1964, the Court's unanimous verdict was to cease procedures against $\mathrm{Ba}^{\mathrm{c}}$ labakkī, to abrogate the payment of any fine, to overturn the original decision to confiscate the copies of the book, and to return the confiscated books to their owners. ${ }^{18}$

Not a few literary works were described as pornography and banned in various Arab countries. Ihsān ${ }^{\mathrm{c}} \mathrm{Abd}$ al-Quddūs (1919-1990), for example, was accused of provoking "sexual disturbances" (shaghab jins $\vec{l}$ ), and even President ${ }^{\mathrm{c}} \mathrm{Abd}$ al-Nāșir expressed his reservations on the novel al-Banāt wa-l-sayf (The girls and the summer) ${ }^{19}$ for its explicit descriptions. ${ }^{20}$ Hikayat Zahra (The story of Zahra) (1980) by the Lebanese Hanān al-Shaykh (b. 1945), which nine publishers in Beirut had turned down before the author decided to publish it herself, was dismissed as pornography and banned in some countries. ${ }^{21}$ Hadīqat alhawāss (The garden of the senses) (1993) by the Lebanese ${ }^{\mathrm{c}}$ Abduh

li-l-Tibā $\bar{c}^{\mathrm{c} a}$ wa-l-Nashr, 1964 [1963]). For an English translation of the title story, see Denys Johnson-Davies, Modern Arabic Short Stories (London: Heinemann, 1981 [1967]), 128-34; Middle Eastern Muslim Women Speak, ed. Elizabeth Warnock Fernea and Basima Qattan Bezirgan (Austin \& London: University of Texas Press, 1977), 274-79.

18 For an account of the trial and the court decision, see Fernea and Bezirgan 1977, 280-90; Roger Allen, Modern Arabic Literature (New York: The Ungar Publishing Company, 1987), 72-73. Copies of the Hebrew translation of $\mathrm{Ba}^{\mathrm{c}}$ labakkī’s novel Anā ahyā (I am alive) (1958), published in 1961, were confiscated from the bookstores in Israel for harming public morality and for the allegedly anti-Jewish sentiments expressed in the novel (Hannah Amit-Kochavi, "Translations of Arabic Literature into Hebrew: Their Historical and Cultural Background and Their Reception by the Target Culture" [Ph.D. thesis, Tel Aviv University, 1999], 269-72).

${ }^{19}$ Iḥsān ${ }^{\mathrm{c}}$ Abd al-Quddūs, al-Banāt wa-l-ṣayf, Beirut: Dār al-Qalam and alMaktaba al-Hadītha, 1973.

20 See Maḥmūd Fawzī, Ihsānn ${ }^{c}$ Abd al-Quddūs bayna al-ightiyāl al-siyās̄̄ wal-shaghab al-jinsī (Cairo: Madbūlī, 1988), 169-72.

21 The novel was translated into English by P. Ford as The Story of Zahra (London: Readers International, 1986). On the banning of the novel, see the Manchester Guardian, 7 July 2001. 
Wāzin (b. 1957) ${ }^{22}$ was also banned in most of the Arab world. ${ }^{23}$

However, censorship in the Arab world during the twentieth century often focused on works by intellectuals who "resorted to rationalism in their examination of the Muslim Canon." 24 The most notorious case of scholarly censorship may well have been that of Tāhā Husayn's controversial study of pre-Islamic poetry, $F \bar{l}$ al-shic ${ }^{c} r$ al-jāhilī (On Jāhilī poetry) (1926). Claiming that the major portion of pre-Islamic poetry was spurious and being skeptical about the historical truth of some sections in the Qur ${ }^{\circ} \bar{a}$, Husayn states, for example, that the Qur ānic reference to Ibrāhīm in itself did not prove that he had indeed been in Mecca. ${ }^{25}$ The book raised a storm of protests and al-Azhar, Egypt's supreme Muslim authority, brought legal charges against the author, who then the following year published a toned-down version entitled $F \bar{l}$ aladab al-jāhilī (On Jāhilī literature). ${ }^{26}$ It is significant that as late as 1980

$22{ }^{\mathrm{c}}$ Abduh Wāzin, Had̄̄qat al-hawā̄ss (Beirut: Dār al-Jadīd, 1993).

23 On the novel and the sensuality of the text, see Stefan G. Meyer, The Experimental Arabic Novel: Postcolonial Literary Modernism in the Levant (A1bany: State University of New York Press, 2001), 213-22.

24 Aziz al-Azmeh, Islams and Modernities (London \& New York: Verso, 1996), 44.

${ }^{25}$ See Țāhā Husayn, $F \bar{l}$ al-shicr al-jāhilì (Cairo: Dār al-Kutub, 1926), 26. On the intellectual and philosophical sources from which Husayn derived his skepticism, see Abdelrashid Mahmoudi, Țāhā Husayn's Education: From the Azhar to the Sorbonne (Surrey: Curzon, 1998), 56-57, 120-24, 171-73, 198202.

26 Tāhā Husayn, F̄̄ al-adab al-jāhilī (Cairo: Maṭba ${ }^{\mathrm{c}}$ at al-I ${ }^{\mathrm{c}}$ timād, 1927). On this issue, see Pierre Cachia, Tăhā Husayn: His Place in the Egyptian Literary Renaissance (London: Luzac \& Company, 1956), 145-49; Anthologie de la littérature arabe contemporaine: Les essais, tr. Anouar Abdel-Malek (Paris: Éditions du Seuil, 1965), 136-39; Albert Hourani, Arabic Thought in the Liberal Age 1798-1939 (Cambridge: Cambridge University Press, 1986 [1962]), 327; J. Brugman, An Introduction to the History of Modern Arabic Literature in Egypt (Leiden: Brill, 1984), 363; Haggai Erlich, Students and Universities in 20th Century Egyptian Politics (London: Frank Cass, 1989), 78-79; Adūn̄̄s, Hā anta, ayyuhā al-waqt (Beirut: Dār al-Ādāb, 1993), 57-59; Nissim Rejwan, Arabs Face the Modern World: Religious, Cultural, and Political Responses to the West (Gainesville, Florida: University Press of Florida, 1998), 43-53; ' $\mathrm{Abd}$ Allāh Ibrāhīm, al-Thaqāfa al-carabiyya wa-l-marjiciyyāt al-mustacāra: Tadākhul al-ansāq wa-l-mafāhīm wa-rihānāt al- ${ }^{c}$ awlama (Casablanca: alMarkaz al-Thaqāfĩ al- ${ }^{c}$ Arabīi, 1999), 13-51. The text of the prosecution decision against Ṭāhā Husayn was published in Fuṣūl 1-2 (1990). On the place of Ṭāhā 
Ṭāhā Husayn was still described in certain circles in the Arab world as "aiming at destroying Islam."27

Similar cases involved several other outstanding Egyptian writers and intellectuals. One of them was ${ }^{\mathrm{c}} \mathrm{Al} \overline{1}{ }^{\mathrm{c}} \mathrm{Abd}$ al-Rāziq (1888-1966), who in 1925 published a book entitled al-Islām wa-usūul al-hukm (Islam and the principles of authority). ${ }^{28}$ The book aroused a violent reaction in religious circles; consequently it was denounced by a council of the leading scholars of al-Azhar, which pronounced the author unfit to hold any public function. ${ }^{29}$ About sixty years later, Muqaddima fi fiqh al-lugha al${ }^{c}$ arabiyya (An introduction to the philology of the Arabic language) (1980) by Luwīs ${ }^{\mathrm{c}}$ Awad (1915-1990) was banned. Under the pressure of Muhammad Mutawallī Sha ${ }^{c}$ rāwī (1911-1998), even Tawfīq al-Hakīm (1898-1987) was forced to change the title for his series of munājayāt published in 1983 in al-Ahrām, from "Ahādīth maca Allāh" (Conversations with Allāh) into "Ahāāith ma ${ }^{c}$ a nafsì”" (Conversations with myself). ${ }^{30}$ That some of the cases are quite recent illustrates how influential the religious circles have remained until today.

One striking recent case was that of Naṣr Hāmid Abū Zayd (b. 1943), an Egyptian professor of Arabic literature at Cairo University. He was declared a heretic, while his wife, Professor Ibtihāl Kamāl Yūnus (b. 1958), was directed in June 1995 by a religious court to divorce him. The

Husayn's book within the framework of Egyptian intellectual history, see Israel Gershoni, "Egyptian Intellectual History and Egyptian Intellectuals in the Interwar Period," Asian and African Studies 19 (1985): 333-64, esp. 345-50.

27 Ghālī Shukrī, Aqni ${ }^{c}$ at al-irhāb: al-Baḥth ${ }^{c}$ an ${ }^{c}$ almāniyya jadīda (Cairo: alHay a al-Mișriyya al- ${ }^{\mathrm{c}} \bar{A} \mathrm{mma}$ li-l-Kitāb, 1992), 297-98. Cf. Anwar al-Jundī, Ṭāhā Husayn: Hayātuhu wa-fikruhu fì mīzān al-Islām (Cairo: Dār al-I ${ }^{\mathrm{C}}$ tișām; Cairo: Dār al-Anșār, 1977); idem, Ukdhūbatān fì ta rīkh al-adab al-ḥadìth: Ahmad Lutfì al-Sayyid, Ṭāhā Husayn (Cairo: Dār al-Anșār, 1979); ' Abd alMajīd ' ${ }^{c}$ bd al-Salām al-Muhtasib, Ṭāhā Husayn mufakkiran (n.p.: Dār Iḥyāo alTurāth al- ${ }^{\mathrm{c}}$ Arabī, 1978).

$28{ }^{\mathrm{c}} \mathrm{Al} \overline{1}{ }^{\mathrm{c}}$ Abd al-Rāziq, al-Islām wa-uṣūl al-ḥukm (Cairo: Maṭba ${ }^{\mathrm{c}}$ at Miṣr, 1925).

${ }^{29}$ For the text of the judgment, see also al-Manār 26,5 (September 1925): 363-83. For a new edition of the book, as well as the judgment of the council and related documents, see ${ }^{\mathrm{c}} \mathrm{Al} \overline{1}{ }^{\mathrm{c}} \mathrm{Abd}$ al-Rāziq, al-Islām wa-uṣūl al-ḥukm (Beirut: al-Mu ${ }^{\circ}$ assasa al- ${ }^{c}$ Arabiyya li-l-Dirāsāt wa-l-Nashr, 1988). On the case, see also Abdel-Malek 1965, 81-86; Hourani 1986 [1962], 183-92; Meisami and Starkey 1998, 1: 18; Rejwan 1998, 43-53.

30 On these cases, see Shukrī, al-Khurūj ${ }^{c}$ alā al-naș̣, 68-69. 
court accepted a claim, brought by Muslim fundamentalists, that Abū Zayd's writings ${ }^{31}$ proved that he was an apostate from Islam and therefore unqualified to be married to a Muslim woman. In Egypt the Islamic concept of hisba allowed any Muslim to sue another for beliefs thought to harm society. Only following Abū Zayd's case did the Egyptian government restrict the use of hisba to state prosecutors only. The arguments against Abū Zayd were reminiscent of those voiced against Țāhā Husayn. ${ }^{32}$ However, unlike the latter, Abū Zayd enjoyed support from many Arab intellectuals; his situation was even compared to that of the philosopher Ibn Rushd (Averroes) (1126-98) and the astronomer Galileo Galilei (1564-1643). ${ }^{33}{ }^{\mathrm{c}}$ Azīz al- ${ }^{\mathrm{c}}$ Aẓma (Aziz al-Azmeh), for example, reacted by saying that "the reality of modern Arab history guides in the direction of secularism, which has been responsible for the progress of our societies, cultures and lives in general." 34

${ }^{31}$ Especially Nașr Hāmid Abū Zayd, Mafhūm al-nașs: Dirāsa fì culūm alQur ān (Beirut \& Casablanca: al-Markaz al-Thaqāfì al- ${ }^{\mathrm{c}}$ Arabīi, 1990); idem, alKhitāa al-dīñ̄: Ru’ya naqdiyya (Beirut: Dār al-Muntakhab al- ${ }^{\mathrm{c} A r a b i ̄ ~ l i-l-D i r a ̄ s a ̄ t ~}$ wa-l-Nashr wa-l-Tawzī' ${ }^{\mathrm{c}}$ 1992); idem, Naqd al-khițāb al-dīnī (Cairo: Madbūlī, 1995).

32 E.g., "Abd al-Latị̂f Fāyid, "Qiș̣at Abī Zayd," Minbar al-Islām 54,2 (July 1995): $2-7$.

${ }^{33}$ Navid Kermani, "Die Affäre Abu Zayd: Eine Kritik am Religiösen Diskurs und ihre Folgen," Orient 35 (1994): 42; Stefan Wild, "Islamic Enlightenment and the Paradox of Averroes," Die Welt des Islams 36,3 (1996): 390.

34 cAzīz al-" Aẓma, "Nașr Hāmid Abū Zayd fīmā warāà al-idāna wa-mā qablahā," Dirāsāt "arabiyya 11-12 (September-October 1995): 3-7. Cf. Taslima Nasreen's speech in front of the sixty-third international congress of the Poets', Essayists' and Novelists' Club (PEN) in Mexico on 8 November 1996, in which she said: "Secularism is a must for democracy. Religious law and democracy are totally contradictory. ... If we want to enjoy democracy, we have to separate religion and state" (according to al-Akhbār Muslim World News list-“I.A.P." <iapinfo@IAP.ORG> [10 November 1996]). Nasreen, a practicing gynecologist and writer, fled Bangladesh in August 1994 for Sweden after receiving death threats for allegedly insulting Islam in her novel Lajja (Shame) (1993). On the "Nasreen affair," see Bishnupryia Ghosh, "An Affair to Remember: Scripted Performances in the "Nasreen Affair," in Amal Amireh and Lisa Suhair Majaj, Going Global: The Transnational Reception of Third World Women Writers (New York \& London: Garland Publishing, Inc.), 39-83. On the religious and the secular in contemporary Arab life, see al-Azmeh 1996, 41-58. 
In August 1996 two Egyptian civil rights groups warned that the court's decision against Abū Zayd in effect constituted a license for Muslim extremists to murder the couple. According to the Egyptian Organization for Human Rights (EOHR), it was a "death sentence," making Abū Zayd and his wife targets "for armed violent groups trying to carry out Islamic sentences." The Center for Human Rights Legal Aid (CHRLA) warned that the ruling could be perceived by radicals as "a green light to practice lethal intellectual terrorism." Both groups cited the case of Faraj Fawda (Foda), who was assassinated by Muslim extremists in 1993 just days after al-Azhar had described him as being "full of animosity against whatever is Islamic." 35 On 23 September 1996, a coalition of international organizations ${ }^{36}$ condemned the court-ordered divorce as "a flagrant violation of one of the most cherished of human rights - the right of a legally married couple to remain married so long as both parties so desire - as well as the basic right of free expression, including academic freedom." The coalition called on President Husnī Mubārak to speak up publicly for the rights of Abū Zayd and his wife and to support the application by their lawyers to the Court of Cessation to nullify the ruling. "By upholding the right of a civil court to declare an Egyptian citizen an apostate," the coalition asserts, "the ruling has a severe chilling effect on freedom of expression." ${ }^{37}$ Only in December

35 According to a news-wire report on adabiyat@listhost.uchicago.edu (15 August 1996). On Fawda, see Arab Studies Journal 1 (Spring 1993): 16-19.

36 The coalition includes twenty-two human rights, Arab-American, women's rights, academic and other organizations, among them the National Association of Arab Americans, the Arab-American University Graduates, the Muslim Public Affairs Council, the Arab American Institute and the AmericanArab Anti-Discrimination Committee (ADC).

37 According to adabiyat@listhost.uchicago.edu (22 September 1996). On the Abū Zayd affair, see also Kermani 1994, 25-49; 'Alī Harb, "Haql alalghām," in al- 'Unf al-ușullī: Muwājahāt al-sayf wa-l-qalam (London \& Beirut: Riyāọ al-Rayyis, 1995), 234-39; Elie Chalala, “'Apostasy' Charges Threaten Cairo University Professor's Marriage," AlJadid (Los Angeles) 2,10 (August 1996): 8; Muștafā Mahmūd, Ziyāra li-l-janna wa-l-nār (Cairo: Dār Akhbār alYawm, 1996), 107-9; Fouad Ajami, The Dream Palace of the Arabs: A Generation's Odyssey (New York: Pantheon Books, 1998), 212-21; Ami Ayalon, Egypt's Quest for Cultural Orientation, Data and Analysis (The Moshe Dayan Center for Middle Eastern and African Studies, Tel Aviv University, 1999), 36, and the bibliographical references at 43, n. 2. Abū Zayd himself published a book that includes various documents relating to the affair (al-Tafkir fi zaman al-takfir: Didd al-jahl wa-l-zīf wa-l-khurāfa [Cairo: Sīnā li-l-Nashr, 1995]) as 
1996 did an appeals court indefinitely suspend the ruling that Abu Zayd and his wife must divorce. ${ }^{38}$

Nawāl al-Sa ${ }^{\mathrm{c}} \mathrm{d} \bar{w} \overline{1}$ (b. 1931), the Arab world's leading feminist, and her husband Sharîf Hitāta (b. 1923) faced the same threat to their marriage as Abū Zayd and his wife. Following an interview given in March 2001 to the Egyptian weekly al-Maydān, in which al-Sa ${ }^{\mathrm{c}} \mathrm{da} w \overline{1}$ said that the rituals in the hajj pilgrimage had pre-Islamic origins and in which she also called for sexual equality in Muslim inheritance laws, the Egyptian Mufti issued a statement that her opinions were beyond the bounds of Islam. The Islamist lawyer Nabīh al-Wahsh filed a case against her calling for a divorce from her husband in accordance with the concept of hisba. ${ }^{39}$ Based on the previously mentioned decision to restrict the use of hisba to state prosecutors, on 30 July 2001 a Cairo court threw out the petition, ruling that no individual could petition a court to forcibly divorce another person. ${ }^{40}$ The "danger" al-Sa ${ }^{c}$ dāwì's feminist writings pose to traditional society has nevertheless not escaped the vigilance of the Islamist campaign in Egypt, and her name was included on the death lists of radical Islamist groups. ${ }^{41} \mathrm{Al}-\mathrm{Sa}^{\mathrm{c}}$ dāwī's novel Suqūt al-imām (The fall of the Imam) (1987) was seen as a condemnation of ideological religious circles for taking part in the oppression of Arab woman. ${ }^{42} \mathrm{Her}$ novel Jannāt wa-Iblīs (Jannāt and Iblīs [the names of the two protago-

well as a collection of articles and essays by writers and intellectuals supporting his case (al-Qawl al-mufìd fì qadiyyat Abū (sic!) Zayd [Cairo: Madbūlī, 1995]).

38 The Washington Post, 20 December 1996, A49.

39 According to e-mail messages from Sherifa Zuhur on 5, 11, and 17 May 2001. Zuhur and Sondra Hale launched a campaign over the Internet in support of al-Sa ${ }^{c}$ āwi against the attempt to force her separation from her husband on the grounds of her apostasy. On the case, see also the Daily Telegraph, 25 April 2001; $a l-\bar{A} d \bar{a} b$, May-June 2001. See also the news release issued on 27 July 2001 by the International Secretariat of Amnesty International (according to ainews@amnesty.org).

40 According to Reuters, 30 July 2001.

${ }^{41}$ Cf. Judith Miller, God Has Ninety-Nine Names: Reporting from a Militant Middle East (New York: Simon \& Schuster, 1996), 70.

${ }^{42}$ Nawāl al-Sa ${ }^{\mathrm{c}} \mathrm{a} w \overline{1}$, Suqūt al-imām (Cairo: Dār al-Mustaqbal al- ${ }^{\mathrm{c}}$ Arabī, 1987). For an English translation, see Nawal El Saadawi, The Fall of the Imam (tr. Sherif Hetata) (London: Minerva, 1995). On the novel, see Fedwa MaltiDouglas, Men, Women, and God(s) (Berkeley: University of California Press, 1995), 91-117 (for a review of Malti-Douglas's book, see Yearbook of Comparative and General Literature 43 [1995]: 175-77). 
nists]) (1992) was seen as a sequel to Suqūt al-imām. ${ }^{43}$ Its setting is an insane asylum where God and Satan are confined together as patients, and Muslim radicals have been quick to brand the book as blasphemy. ${ }^{44}$

Part of the protest against al-Sa ${ }^{c}$ dāwi was the outcome of her views regarding homosexuality and lesbianism. Although Islam guarantees male homosexuals a place in Hell, ${ }^{45}$ and although, contrary to the past, in

${ }^{43}$ Nawāl al-Sa ${ }^{c}$ dawī, Jannāt wa-Iblīs (Beirut: Dār al-Ādāb, 1992). For the English translation, see Nawal El Saadawi, The Innocence of the Devil (tr. Sherif Hetata; introduction by Fedwa Malti-Douglas), Berkeley: University of California Press, 1994. On the novel, see Malti-Douglas 1995, 118-41 as well as Malti-Douglas' introduction to El Saadawi 1994, xi-xiv.

${ }^{44} \mathrm{Cf}$. Malti-Douglas 1995,6 , 95. On al-Sa ${ }^{\mathrm{c}}$ daw's's attitude to the Islamist discourse, see her essay about al-Ṣādiq al-Nayhūm's book al-Islām fì al-asr (London \& Limassol: Riyạ̣̄ al-Rayyis, 1991) published in al-Ṣādiq al-Nayhūm, Islām ḍidda al-Islām (London \& Beirut: Riyāọ al-Rayyis, 1994), 297-301 (originally published in al-Nāqid 49 [July 1992]). Nawāl al-Sa dawī is mentioned as one of the principal sources from whom Rosalind Miles in her The Women's History of the World (London: Michael Joseph, 1988) and Salman Rushdie in his The Satanic Verses (London: Viking, 1988) got the feminist diatribes against Islam (Ziauddin Sardar and Merryl Wyn Davies, Distorted Imagination: Lessons from the Rushdie Affair [London: Grey Seal; Kuala Lumpur: Berita, 1990], 168). Miles sees monotheistic religions as conspiracies and plots against women: "The result of divine inspiration transmitted from a male power to males empowered for this purpose, thereby enshrining maleness itself as power" (Miles 1988, 59; cf. Sardar and Davies 1990, 165-76). On the Rushdie affair, see below.

45 See Charles Pellat, "Liwāt," in Sexuality and Eroticism among Males in Moslem Societies, ed. Arno Schmitt and Jehoeda Sofer (New York: Harrington Park Press, 1992), 152. On homosexuality in Islam in general, see al-Ghazzālī, Marriage and Sexuality in Islam: A translation of al-Ghazālī's Book on the Etiquette of Marriage from the Ihyā, tr. Madelain Farah (Salt Lake City, Utah: University of Utah Press, 1984), 37-39; Ch. Pellat, "Liwāt,", The Encyclopaedia of Islam, New Edition, 5 (1986): 776-79 (see an enlarged version in Pellat 1992, 151-67); and Arno Schmitt, "Liwāt im Fiqh: Männliche Homosexualität?” Journal of Arabic and Islamic Studies 4 (2001-2002): 49-110. On lesbianism in Muslim societies, see G. H. A. Juynboll, "Sihāk," The Encyclopaedia of Islam, New Edition, 9 (1997): 565-67, including the detailed bibliography. On the study of homosexuality in Arab/Islamic civilization, see Asad AbuKhalil, "A Note on the Study of Homosexuality in the Arab/Islamic Civilization," Arab Studies Journal 1 (Fall 1993): 32-34; Mohamed Sadek, Letter to the Editor: Response to "A Note on the Study of Homosexuality in the Arab/Islamic Civilization," Arab Studies Journal 2 (Spring 1994): 65. On 
the modern period it has never been easy to be homosexual in Egypt, ${ }^{46}$ the subject has frequently appeared in highbrow Arabic fiction, and several novels and films portray homosexual characters living normally in society and causing no public outcry. ${ }^{47}$

In May 2000 the Islamist-oriented opposition Labor Party and its newspaper $a l-S h a^{c} b$ led a public campaign against the novel Walima li$a^{c}$ shāb al-bahr (A banquet for seaweed) (1983) by the Syrian writer Haydar Haydar (b. 1938), saying it defamed Islam and denigrated the Prophet Muhammad and the Qur ${ }^{\supset} \mathrm{a}$. They demanded the resignation of the Culture Minister because his ministry had reprinted the novel. ${ }^{48}$ Fol-

Western attitudes to homosexuality in the Middle East, see Derek Hopwood, Sexual Encounters in the Middle East: The British, the French and the Arabs (Reading: Ithaca Press, 1999), 175-82. On effeminates in medieval Arabic literature, see Everett K. Rowson, "The Categorization of Gender and Sexual Irregularity in Medieval Arabic Vice Lists," in Body Guards: The Cultural Politics of Gender Ambiguity, ed. Julia Epstein and Kristina Straub (New York \& London: Routledge, 1991), 50-79; idem, "The Effeminates of Early Medina," Journal of the American Oriental Society 111.4 (1991): 671-93; Shirley Guthrie, Arab Women in the Middle Ages: Private Lives and Public Roles (London: Saqi Books, 2001), 196-199. On the role of the mukhannathün in semi-dramatic scenes in medieval times, see Shmuel Moreh, Live Theatre and Dramatic Literature in the Medieval Arabic World (Edinburgh: Edinburgh University Press,

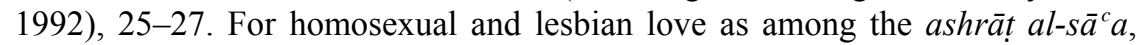
that is, the signs of the end of time and resurrection, see Abū 'Uthmān al-Jāhiz, Ras $\bar{a}^{\supset} i l$, ed. ' Alī Abū Milhim (Beirut: Dār wa-Maktabat al-Hilāl, 1991), 1: 151;

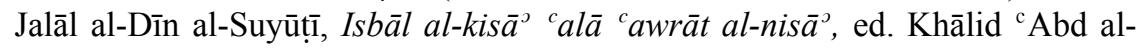
Karīm Jum ${ }^{\mathrm{c} a}$ and ${ }^{\mathrm{c}} \mathrm{Abd}$ al-Qādir Aḥmad ${ }^{\mathrm{c}} \mathrm{Abd}$ al-Qādir (Kuwait: Dār al- ${ }^{\mathrm{c} U} \mathrm{U} u \bar{b} a$ li-l-Nashr wa-1-Tawzīc , 1990), 70.

${ }^{46}$ See Brian Whitaker, "Homosexuality on Trial in Egypt," The Guardian, 19 November 2001.

${ }^{47}$ E.g., the character of Kirsha in Najīb Mahfūz's Zuqāq al-Midaqq (Cairo: Dār Miṣr, n.d. [1947]); the short story "Abū al-Rijāl" by Yūsuf Idrīs from the collection al- ${ }^{c}$ Atab ${ }^{c}$ alà al-nazar (Cairo: Markaz al-Ahrām li-l-Tarjama wa-lNashr, 1987), 69-99. For an English translation, see Youssef Idris, A Leader of Men (Fredericton: York Press, 1988). On the story, see P. J. Vatikiotis, "Vanishing Cultural Bridges between East and West," Asian and African Studies 25 [1991]: 182. See also "Abd al-Qādir al-Janābī, Tarbiyat ' $A b d$ al-Qādir alJanābī (Beirut: Dār al-Jadīd), 61. For homosexuality in Egyptian films, see Walter Armbrust, Mass Culture and Modernism in Egypt (Cambridge: Cambridge University Press, 1996), 254-55, n. 44.

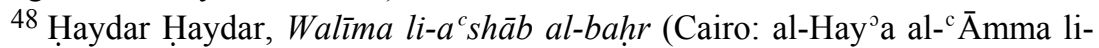


lowing clashes with the police, in which dozens of students were wounded, the Egyptian authorities effectively froze for a time the activities of the Labor Party and closed $a l-S h a^{c} b{ }^{49}$ Haydar himself said that the campaign against the novel was based on passages taken out of context. ${ }^{50}$ In a press release on 9 May 2000, EOHR expressed its alarm over the apostatizing campaign against Haydar as well as against the Egyptian writer Idwār (Edward) al-Kharrāṭ (b. 1926). Warning that judgment of creative works on other than artistic considerations threatened to impose religious or political custodianship on human thought, the organization mentioned that past experience had proved the intensity of the discourse could erupt into bloody violence. ${ }^{51}$

Similar cases were not rare even in Arab states known for their openness. In Lebanon, which has long been regarded as "the most liberal state in the Arab world," 52 the Baclabakki case described above was not the only instance of the kind. Thus intellectuals who resorted to rationalism in their writings were exposed to legal proceedings here as well. In December 1969 Ṣādiq Jalāl al-c Aẓm (b. 1934) was jailed for several days following the publication of his book Naqd al-fikr al-dinni (The criticism of religious thought) (1969). A multi-sectarian society, Lebanon has laws prohibiting the slander of religion and religious figures. Al- ${ }^{\mathrm{c}} \mathrm{Azm}$ and the publisher Bashīr Dā $\bar{a}^{c} \bar{q}$, owner of the Lebanese Dār al-Ṭalî $a$, were accused of offending Christian, but especially Muslim religion. In July

Qușūr al-Thaqāfa, 2000). The first edition of the novel, which had been written between 1974 and 1983 in Algeria, Beirut and Cyprus, appeared in Beirut in 1983 at the author's expense after publishers had refused to publish it. A second edition was published by Dār Amwāj in Beirut in 1988. On the novel, see Adab wa-naqd 21 (April-May 1986): 25-54.

49 According to Reuters, 20 May 2000. Muhammad Salamāwī (b. 1945), foreign editor of al-Ahräm, explained that the demonstrations should be seen as an attempt by the Muslim extremists to strengthen their position in the internal political arena (BBC World Service, 9 May 2000). On the controversy surrounding Haydar Haydar's novel and the political protest the novel ignited, see also the New York Times, 9 May 2000, A5; AlJadid (Los Angeles), 31. In al-Ādāb, JulyAugust 2000, 'Abd al-Razzāq 'Īd argues against a "secular" interpretation that "kills" the novel while "protecting" the writer from possible death. On the case, see also Muḥammad 'Abbās, al-Wacy yanzifu min thuqūb al-dhākira (Cairo: Maktabat Madbūlī, 2001).

50 According to Associated Press, 13 May 2000.

51 According EOHR's Webpage (http://www.eohr.org.eg).

52 Hafez 2001, 27. 
1970 both of them were found not guilty. ${ }^{53}$ In September 1996 the Lebanese composer, ${ }^{c} \bar{u} d$ (oud) player and singer Marcel Khalīfa (Khalife) (b. 1940) was charged with blasphemy when he included a verse from the Qur”ān about the Biblical figure Joseph in his song "Anā Yūsuf yā abī" (O my father, I am Yūsuf) released in 1995 on the album Rakwat carab (Arabic coffeepot). Khalīfa, who won a cult following in the Arab world and the Arab diaspora through his nationalistic songs during the Lebanese civil war, and who draws thousands of people to his concerts, was alleged to have "insulted Islam." The music of the song is Khalifa's while the lyrics are based upon a poem by the Palestinian poet Mahmūd Darwīsh (b. 1941), from his collection Ward aqall (Fewer roses), the poems in which were inspired by the Lebanese war of 1982 and its aftereffects:

$$
\begin{aligned}
& \text { أنا يوسف يا أبي. يا أبي، إخوتي لا يحبّونني، لا يريدونني بينهم يا }
\end{aligned}
$$

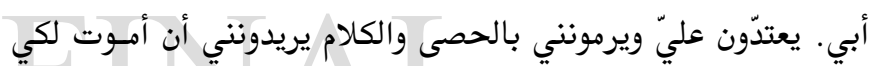

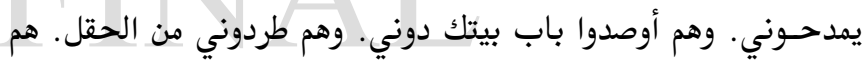

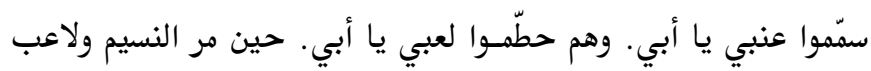

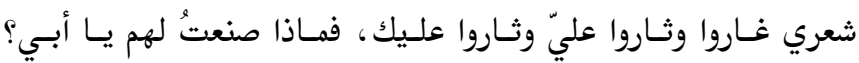

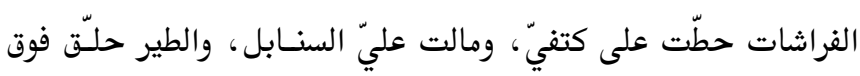

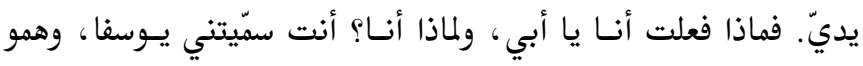

$$
\begin{aligned}
& \text { أوقهوني في الجبّ، واتِهموا الذئب؛ والذئب أرحم من إخوتي، أبت! } \\
& \text { هل جنيت على أحد عندما قلت إني رأيت أحد عشر كوكبا، والشمس } \\
& \text { والقمر، رأيتهم لي ساجدين }
\end{aligned}
$$

$\mathrm{O}$ my father, I am Joseph. O father, my brothers neither love me nor want me in their midst, $\mathrm{O}$ my

Father, they assault me and cast stones and words at me. They want me to die so They can eulogize me. They closed the door of your house and left me outside. They expelled me from the field. They

Poisoned my grapes, $\mathrm{O}$ my father. They destroyed my toys, $\mathrm{O}$ my father. When

${ }^{53}$ For the book, see Șādiq Jalāl al- ${ }^{\mathrm{c}}$ Aẓm, Naqd al-fikr al-dīn (Beirut: Dār al$\mathrm{Tali}^{\mathrm{c}} \mathrm{a}, 1988$ [1969]). Some documents of the trial of the writer and the publisher appear in the appendix attached to the book (146-60). 
the passing gentle wind played with

My hair they were jealous, they flamed up with rage against me and you. What did I do to them, $\mathrm{O}$ my father?

The butterflies stopped on my shoulder, the ears of grain bent down to me and the birds hovered over

My hands. What have $I$ done, $\mathrm{O}$ my father? And why me? You named me Joseph and they

Threw me into the well and accused the wolf, though the wolf is more merciful than my brothers, $\mathrm{O}$ my father!

Did I wrong anyone when I said that I saw eleven stars, and the sun

And the moon, I saw them bowing down before me. ${ }^{54}$

The last lines use the fourth verse from Sürat Yüsuf, in which Joseph addresses his father Jacob (both revered in Islam as prophets):

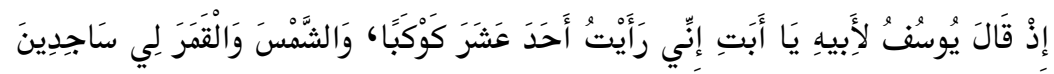

When Joseph said to his father, "Father, I saw eleven stars, and the sun and the moon; I saw them bowing down before me."

As in other poems included in Ward aqall, Darwish describes in the poem the suffering of the Palestinian Joseph at the hands of his brothers. A similar theme appears in "Yucāniqu qātilahu" (Embracing his murderer) from the same collection, in which the story of Cain and Abel is used to illustrate how the Palestinian Abel embraces his brother Cain who is about to slay him. With Cain unwilling to relent, Abel strives desperately to gain his brother's mercy. 55

'Abd Allāh Bītār (Bayțār), the chief prosecutor of Beirut, charged Khalifa with blasphemy, even though the singer had obtained permission from Lebanon's General Security Censorship Bureau to release the song. ${ }^{56}$ Under article 473 of Lebanon's penal code, blasphemy in public

54 Mạ̣mūd Darwīsh, Ward aqall (Acre: Dār al-Aswār, 1987), 77. For another translation by Manal Swairjo, see alJadid 28 (Summer 1999): 16.

55 Darwīsh 1987, 33. For another poem, by Mūsā Hawāmida, that employs the story of Joseph, see Salāh Faḍl, Tahawwulāt al-shic riyya al- ${ }^{c}$ arabiyya (Beirut: Dār al-Ādāb, 2002), 165-67.

56 A similar charge was brought against the Lebanese writer André Haddād for his book The Entry to Arab Union, which allegedly questioned the relevance of Islam because of a passage that says: "Islam is not qualified to accompany the development that the world is witnessing and does not give room to those of other religions to hold public office." Both Khalīfa and Haddād are Maronite Christians. 
is punishable by one month to one year in prison. Article 474 of the penal code authorizes imprisonment of six months to three years for publicly insulting a religion. ${ }^{57}$ Khalīfa's was an interesting test case because, while some Muslim clerics maintain that all singing of the Qur ${ }^{\circ} \overline{\mathrm{a}}$ is forbidden, other clerics have had no qualms about making such lyrical recordings. Also, of course, Qur ${ }^{\circ} \bar{a}$ nic verses, whether in the original Arabic, or translated Persian, have routinely been used in Iranian revolutionary songs since 1978.58 Perhaps that was the reason why the Higher Shiite Council in Lebanon, while issuing a statement that Islamic law does not allow verses from the Qur ${ }^{\circ} \bar{n}$ to be included in popular songs, was at variance with the drive to try Khalīfa. ${ }^{59}$

Muslim and Christian poets, writers, scholars and journalists said they were disgusted by the charges against Khalīfa, calling them bizarre and reminiscent of campaigns waged against intellectuals in some Islamic countries. Reacting to the charges against Khalīfa, Professor Stephen P. Sheehi, an American intellectual and scholar of Lebanese descent, said that this was a politically motivated witch hunt by Prime Minister Harīī in order "to intimidate, if not silence, his critics." ${ }^{60}$ Addressing the prosecutor, the Lebanese poet Paul Shā $\bar{u}^{\top}$ (b. 1942) put it: "Sir, you were preceded in your edict by those who issued edicts in Egypt, Sudan, India and Pakistan and before them the Inquisition courts of the dark Middle Ages." Another poet, Shawqī Bazīgh (b. 1951), said that the charges against Khalīfa as well as against the writer al-Sādiq al-Nayhūm (19371994), and the confiscation in 1991 of his books that were considered an offense to Islam ${ }^{61}$ "falsify Beirut's spirit and role" as a cultural center. ${ }^{62}$

${ }^{57}$ Based upon a United Press International news-wire report from Beirut, 19 September 1996 (according to adabiyat@listhost.uchicago.edu [distributed same date]).

58 Based on early Islamic tradition, listening to the recital of the Qur $\bar{a} n$ accompanied by music is considered by certain scholars to be a sin of disobedience to God (M. J. Kister, "'Exert Yourselves, O Banū Arfida!': Some Notes on Entertainment in the Islamic Tradition," Jerusalem Studies in Arabic and Islam 23 [1999]: 61). On the issue of setting verses of the $Q u r^{\circ} \bar{a} n$ to music, see Diyā al-Dīn Baybars, "Talhīn al-Qurª̄n bayna ahl al-fann wa-rijāl al-dīn," al-Hilāl, December 1970, 118-27.

${ }^{59}$ Elie Chalala, "Marcel Khalife Faces Charge over Darwish Poem: Arab Intellectuals Rally to Defend Creative Freedom," AlJadid (Los Angeles) 28 (Summer 1999): 7.

60 According to adabiyat@listhost.uchicago.edu (20 September 1996).

${ }^{61}$ On al-Ṣādiq al-Nayhūm's outlooks and the reactions to them, see al- 
"It is as if we face a new version of the saga of Youssef Chahine [Y ūsuf Shāhīn, b. 1926] and his film The Emigrant [al-Muhājir],"63 wrote another poet. 64

Darwīsh himself criticized the legal proceedings in an interview with the Lebanese newspaper al-Diyār on 10 October 1999 stating that fundamentalism is in the process of stifling culture and creation in the Arab world: "We should all be ashamed. If Khalifa is found guilty, it will be an insult to culture." 65 On 2 October 1999, the newly appointed investigating judge, ${ }^{\mathrm{c}} \mathrm{Abd}$ al-Rahmmān Shihāb, recommended that prosecutors

Nayhūm 1991 and al-Nayhūm 1994.

${ }^{62}$ Cf. AlJadid (Los Angeles) 28 (Summer 1999): 8-9.

${ }^{63}$ On how Shāhīn's controversial film narrowly escaped being banned for allegedly depicting Joseph, see Wild 1996, 389-90 and the references in nn. 21, 22; Ayalon 1999, 33. During the fiftieth annual Cannes Film Festival (May 1997), a special lifetime achievement award was presented to Shāhīn. On Shāhīn in general, see Claude Michel Cluny, Dictionnaire des nouveaux cinémas arabes (Paris: Sindbad, 1978), 161-72; Muhammad al-Șāwī, Sinnimā Yūsuf Shāhīn: Rihla Aydiyūlüjiyya (Alexandria: Dār al-Maṭuū àt al-Jadīda, 1990); Hind Rassam Culhane, East/West, an Ambiguous State of Being: The Construction and Representation of Egyptian Cultural Identity in Egyptian Film (New York: Peter Lang, 1995), 49-56, 71-75; Mustafa Darwish, Dream Makers on the Nile: A Portrait of Egyptian Cinema (Cairo: The American University in Cairo Press, 1998), 43; Sharon A. Russell, Guide to African Cinema (Westport, CT: Greenwood Press, 1998), 47-50. On the attempt to ban Umm Kulthūm's singing of Rubā ciyyāt al-Khayyām translated by Aḥmad Rāmī (Beirut: Dār al'Awda, 1977), see Sélim Nassib, Oum (Paris: Balland, 1994), 193-96 (=Salīm Turkiyya, Kāna șarhan min khayāl, tr. Bassām Hajjār [Beirut: alMasār, 1999], 208-11).

64 Based upon a Reuters news-wire report from Beirut, 21 September 1996 (according to adabiyat@listhost.uchicago.edu [22 September 1996]). Following Khalîfa's case the journal AlJadid (Los Angeles) dedicated an issue to the freedom of artists, intellectuals and media in Lebanon (2.11 [September 1996]). Among the articles published in this issue "Arab Artists, Intellectuals, Condemn Charges Against Khalife as Attack on Liberty, Civil Freedom," by Elie Chalala; a special article by Marcel Khalifa in which he reflects on his American tour and other issues, "We Turn the Page from City to City"; "Marcel Khalife and the Modern Inquisition," by Paul Sha ${ }^{\top} \bar{u}$; "Lebanese Media Restrictions Stir Broad Opposition," by Michelle A. Marzahn. On the case, see also AlJadid (Los Angeles) 28 (1999). On the general issue of freedom of expression in Lebanon, see Samāh Idrīs's editorial in al-Ādāb 11-12 (1999).

${ }^{65}$ According to Human Rights Watch < hrwatchnyc@igc.org> (1 November 1999). 
bring criminal charges against Khalifa for "insulting religious values," and the next day senior Sunnī Muslim clerics in Lebanon ruled that singing verses from the Koran was "absolutely banned and not accepted." The highest Sunnī Muslim religious authority in Lebanon, Grand Mufti Muhammad Rāshid Qabbān̄̄, maintained that "there is a limit to freedom of expression. One limit is that it should not infringe on people's religious beliefs." In reply, Hanny Megally, executive director of Human Rights Watch's Middle East and North Africa division, said that this case is a direct legal challenge to the right to freedom of expression in Lebanon. ${ }^{66}$ In another move the American-Arab Anti-Discrimination Committee (ADC) encouraged intellectuals throughout the world to sign a petition on behalf of the singer, saying that the charges against him are a "flagrant violation of intellectual freedoms which should be guaranteed to artists in all countries. ... In fact, the song is dedicated to the people of Lebanon and Palestine, referring symbolically to their suffering, using the narrative of the Prophet Joseph's famous story." ${ }^{\prime 67}$ In the middle of December 1999 Khalifa was cleared by the court of any guilt. ${ }^{68}$

This was not the first time charges of blasphemy had been leveled against singers in the Arab world. For example, in two previous cases, poems that the Egyptian musician and singer Muhammad ${ }^{\mathrm{c}} \mathrm{Abd}$ alWahhāb (1901-1991) set to music and sang were involved: "al-Ṭalāsim" (The talismans), written by the Mahjarī poet Īliyyā Abū Māḍi (18891957), ${ }^{69}$ and "Min ghayr leh" (Without asking why), written by the singer himself. 70

\footnotetext{
${ }^{66}$ According to Human Rights Watch $<$ hrwatchnyc@igc.org> $(1$ November 1999).

67 According to msanews@msanews.mynet.net (MSANEWS) (19 October 1999).

68 According to Ha'aretz (Tel Aviv), 19 December 1999, A3.

${ }^{69}$ For the original poem, known for its repeated phrase lastu adrī (I do not know), see Īliyyā Abū Māẹī, Dīwān (Beirut: Dār al- ${ }^{\mathrm{c}} \mathrm{A} w d a$, n.d.), 191-214.

70 On the poem and the attempt to ban it, see Karin van Nieuwkerk, " $A$ Trade Like Any Other": Female Singers and Dancers in Egypt (Austin: University of Texas Press, 1995), 65. The Jewish writer of Iraqi origin Mnashshī $\mathrm{Za}^{\mathrm{c}}$ rūr (1897-1972) mentioned in an interview (al-Sharq, May-June 1977, 63) that Abū Mādī̄s poem is similar to an Iraqi popular song in which the concluding words are:
}

$$
\begin{aligned}
& \text { أنسا مـنــــين وأنـت مــــين } \\
& \text { تسـايه دلسوني والطريق منسين }
\end{aligned}
$$


Also in Kuwait, which used to be an island of relative openness in the Middle East, Islamists, basing themselves on Kuwait's Press and Publications Law, brought a series of cases against journalists, writers, and academics for expressing controversial views on religious and political themes. The law makes it a criminal offense to publish materials that abuse "by allusion, slander, sarcasm, or disparagement, God or the prophets or the companions of the prophet Muhammad," or that "sully public morals." A similarly vague article in the Criminal Code mandates prison sentences for the dissemination of "opinions that include sarcasm, contempt, or belittling of religion or a religious school of thought." For example, University professor Aḥmad al-Baghdādī was sentenced to one month in prison in October 1999 after the court found that an article by him in a student newspaper defamed Islam by contending that the Prophet Muhammad had failed to convert non-believers during his time in Mecca. He was later pardoned due to his poor health. Other rulings in 1999 have resulted in journalists being fined and publication of their magazines and newspapers ordered suspended. On 22 January 2000 a Kuwaiti court sentenced ${ }^{\mathrm{c}} \mathrm{A}$ liya $\mathrm{Shu}^{\mathrm{c}}$ ayb, a Kuwait University professor of philosophy, her publisher Yahyā al-Ruba ${ }^{c} y a \bar{n}$, and the short story writer and novelist Laylā al- ${ }^{\mathrm{c}}$ Uthmān (b. 1944) to two months in prison for writings that the court said "included expressions that defy God, and indecent and shameless expressions." In addition to the prison sentences, Shu $u^{c}$ ayb and al-Ruba ${ }^{c} y a \bar{n}$ were each fined 100 dinars for the publication and distribution without a permit of Shu'ayb's book of poetry 'Anākib tarthī jurhan (Spiders bemoan a wound). ${ }^{71}$ Hanny Megally, mentioned earlier, from Human Rights Watch remarked that "this kind of legislation provides an opening for the arbitrary prosecution of almost any kind of speech or writing." 72

The above-mentioned cases of censorship and the struggle for freedom of expression that accompanied each of them shed light on the fact that Arab culture since the nineteenth century has gradually been detaching itself from subjection to the religious factor alone. Signs highlighting the acceleration of this development have been both organizational and social, important examples being the establishment in Berlin in 1998 of the non-governmental Ibn Rushd Fund for Freedom of Thought and the thorny Rushdie affair and its implications in the Arab world.

\footnotetext{
71 On the collection, in light of the case, see Fadl 2002, 153-59.

72 According to "Human Rights Watch < hrwatchnyc@igc.org>" (25 January 2000). See also AlJadid (Los Angeles) 29 (1999).
} 


\section{Signs of Gradual Change}

Often considered the supreme mediator between the Arab world and the West, Ibn Rushd (1126-1198), known as Averroes in Europe, was celebrated for his efforts to reconcile philosophy and religion. In the spirit of the man whose name it took, the Ibn Rushd Fund for Freedom of Thought, established on the occasion of the 800th anniversary of Ibn Rushd's death, was dedicated to the support of the right to free speech and democracy in the Arab World. The Fund established a prize to be awarded annually to organizations or persons having rendered outstanding service to the right of free speech and democracy. The Ibn Rushd Prize was awarded for the first time in Berlin on the occasion of the first anniversary of the Fund's foundation on 10 December 1999 to the private TV station al-Jazira (The Island [Peninsula]) Satellite Channel (Qatar), in order "to support the existence of this medium so important to democracy and freedom of speech in Arab countries." Founded only in 1996, the station had soon become a source for information for Arabs throughout the world, a role that took on special significance after 11 September 2001.

Unlike other Arab mass media, which are subject to their respective heads of state, who use them as instruments to achieve legitimacy and channels to convey their politics, al-Jazinra has become a forum for democratic discourse about current topics and events, whether of a political nature, such as the Arab-Israeli conflict, or of a social nature, such as the emancipation of women and the defense of human rights, or even religious themes, such as Islam and democracy and political Islam. According to Muhammad Jāsim al- ${ }^{\mathrm{c}} \mathrm{Alī}$, al-Jazìra's chief editor, "Other TV stations hold too many taboos. We do not know any taboos. Our audience have a right to the truth." According to the station's owner Shaykh Hamad ibn Thāmir al-Thān̄̄, "the neighboring oil countries seem to fear a cultural revolution, because Al Jazeera is like a virus, a contagious virus exercising a positive influence on freedom of speech in other Arab countries." Described after its name, by the awarders of the prize, as "an island of freedom of speech," the station has been the target of criticism from all quarters. For example, the station's office in Kuwait was closed after the Emir felt insulted by one of the programs the channel broadcasted. "On another occasion," the awarders note, "US diplomats tried to keep the station from broadcasting an interview with Osama Bin Laden."73 Similar incidents occurred following the commencement of

\footnotetext{
${ }^{73}$ The citations relating to the Ibn Rushd prizes, here and below, and other details are contained in the English press releases concerning the prizes for the
} 
the wars in Afghanistan and Iraq. ${ }^{74}$

The second Ibn Rushd Prize for Freedom of Thought (2000) was awarded to the Palestinian Women's Rights Activist 'Ișām 'Abd alGhanī 'Abd al-Hādī (b. 1928), President of the General Union of Palestinian Women, for her "outstanding services to women's rights in the Arab World." The Egyptian scholar and thinker Mahmūd Amīn al- ${ }^{c} \bar{A} l i m$ (b. 1922) received the third Ibn Rushd Prize (2001). He was honored "for his struggle for freedom and democracy, for his critical thinking and his political commitment, for his writings and analyses, his engagement in support of open dialogue and services to a culture of rational dispute and enlightenment." The fourth Ibn Rushd Prize (2002) was awarded to Dr. 'Azmī Bishāra, an Arab member of the Israeli Knesset "for special contributions to freedom of speech and democracy in the Arab World." The fifth went to the Algerian-born scholar Mohammed Arkoun (b. 1928) for his championing a dialogue between cultures - "his comparative approach to religions and cultures make him a modern-time Ibn Rushd." The sixth was given to the Egyptian writer Șunc Allāh Ibrāhīm (b. 1937) for encouraging "the reader to resist and not to tolerate the deplorable state of affairs, but to fight them."

Against the background of the activities of the Ibn Rushd Fund for Freedom of Thought in Berlin, which are admittedly marginal from the point of view of culture inside the Arab world, the Rushdie affair and its implications reflect, retrospectively, a more gradual change in the relationship between religion and literature inside the Arab world, especially if we compare it with a previous similar affair involving the Egyptian writer Najīb Mahfüz (b. 1911). Although an interval of 30 years separates the two cases, both of them intersect to uncover the fact that a significant change took place during the period. The international furor surrounding The Satanic Verses (1988) by Salman Rushdie (b. 1947) ${ }^{75}$ was

relevant year at http://www.ibn-rushd.org (27 April 2005).

${ }^{74}$ On al-Jazira's coverage following the events of 11 September 2001, see the biannual electronic journal Transnational Broadcasting Studies (the Adham Center for Television Journalism at the American University in Cairo) (www.tbsjournal.com), Fall/Winter 2001 issue.

75 Rushdie 1988. On the novel against the background of the Rushdie Affair, see Timothy Brennan, Salman Rusdhie and the Third World (New York: St. Martin Press, 1989), esp. 143-66; John Erickson, Islam and Postcolonial Narrative (Cambridge: Cambridge University Press, 1998), 129-60; Minou Reeves, Muhammad in Europe (New York: New York University Press, 2000), 271300. On the Rushdie Affair in general, see The Rushdie File, ed. Lisa Appig- 
engendered by the death sentence hurled at him in the fatwa given by Āyatullāh Rūhullah Khumaynī (1902?-1989), the spiritual head of Iran after the Revolution of 1979:

I inform the proud Muslim People of the world that the author of The Satanic Verses, which is against Islam, the Prophet and the Qur'an, and all involved in its publication who are aware of its content are sentenced to death. I request brave Muslims to quickly kill them wherever they find them so that no one ever again would dare to insult the sanctions of Muslims. Anyone killed in trying to execute Rushdie would, God willing, be a shaheed (martyr). In addition, anyone who has access to the author of the book but does not have the strength to execute him should introduce him to the people so that he receives punishment for his action. ${ }^{76}$

This fatwa $\bar{a}$ was prompted in particular by a description, in a chapter entitled "Return to Jahilia," of a popular brothel given the name Hijab in the city of Jahilia, where the whores had each assumed the identity of one of the Prophet Muhammad's wives:

The fifteen-year-old whore 'Ayesha' was the most popular with the paying public. ... The oldest, fattest whore, who had taken the name of 'Sawdah' ... The whore 'Hafsah' grew as hot-tempered as her namesake. ... 'Umm Salamah the Makhzumite' and, snootiest of all, 'Ramlah' ... And there was a 'Zainab bint Jahsh', and a 'Juwairyah' ... and a 'Rehana the Jew', a 'Safia' and 'Maimunah', and, most erotic of all whores, who knew tricks she refused to teach to competitive 'Ayesha': the glamorous Egyptian, 'Mary the Copt'. Strangest of all was the whore who had taken the name of 'Zainab bint Khuzaimah'. ${ }^{77}$

nanesi and Sara Maitland (Syracuse: Syracuse University Press, 1990); Malise Ruthven, A Satanic Affair: Salman Rushdie and the Rage of Islam (London: Chatto \& Windus, 1990); Sardar and Davies 1990; "Eine Chronik des Falls Salman Rushdie," Zeitschrift für Kulturaustausch, no. 4 (1992): 539-88; John L. Esposito, The Islamic Threat: Myth or Reality (New York \& Oxford: Oxford University Press, 1992), 190-93; John C. Hawley, Postcolonial Crescent: Islam's Impact on Contemporary Literature (New York: Peter Lang, 1998), 1-31, 84-92. On the affair with regard to Orientalism and postcolonial discourse, see Anouar Majid, Unveiling Traditions: Postcolonial Islam in a Polycentric World (Durham \& London: Duke University Press, 2000), 22-49.

76 Sardar and Davies 1990, 193-94; Ruthven 1990, 112.

${ }^{77}$ Rushdie 1988, 381-82. Cf. $M$ to the Nth Degree by the Greek author Mimis Androulakis, in which a couple of pages give a steamy account of Mary Magdalene's imaginary relationship with Christ. Consequently the novel was denounced by religious groups such as the Greek Orthodox Salvation Movement as "insulting the religious conscience and personality of every Greek 
Another stimulus for the fatwā was the riwayyat al-gharānīq (the narration of the cranes), on which the title of the novel is based-verses that were allegedly transmitted by the Prophet Muhammad as part of the Qur ${ }^{\circ} a \bar{n} i c$ revelation. In these verses Satan inspired Muhammad to praise the idols al-Lāt, al- ${ }^{c} U z z \bar{a}$ and Manāt, calling them al-gharānīq al- ${ }^{c} u l \bar{a}$ (the lofty cranes). However, the Prophet later realized that he had been tricked by Satan and withdrew the verses, ${ }^{78}$ transmitting others in their place. ${ }^{79}$ Rushdie deals with this story in the second chapter of the novel, entitled "Mahound," which concludes with the following words:

Mahound has reached his oasis: Gibreel is not so lucky. Often, now, he finds himself alone on the summit of Mount Cone, washed by the cold, falling stars, and then they fall upon him from the night sky, the three winged creatures, Lat Uzza Manat, flapping around his head, clawing at his eyes, biting, whipping him with their hair, their wings. He puts up his hands to protect himself, but their revenge is tireless, continuing whenever he rests, whenever he drops his guard. He struggles against them, but they are faster, nimbler, winged. He has no devil to repudiate. Dreaming, he cannot wish them away. ${ }^{80}$

Khumaynī's fatwa $\bar{a}$ reawakened the radical religious circles in Egypt against Najīb Mahfūz, whom they accused, together with Rushdie, of apostasy. ${ }^{81}$ Surprisingly enough, the accusation against Mahfüz was due to a novel he had published almost 30 years before The Satanic Verses, namely, Awlād häratinā (Children of our alley) (1959), ${ }^{82}$ which was

Christian" (Times [London], 20 may 2000, 16).

78 Sürat al-hajj (22):52: "Allāh abrogates that which Satan proposes."

${ }^{79}$ Sürat al-najm (53):19-23.

${ }^{80}$ Rushdie 1988, 126. On the story of this naskh (abrogation), see $\mathrm{Ta}^{\mathrm{r}} \mathrm{rikh}$ alṬabarī, ed. Muhammad Abū al-Faḍl Ibrāhīm (Cairo: Dār al-Ma ${ }^{\mathrm{c}} \bar{a}$ rif, 1961), 338-40; al-Azmeh 1996, 115, as well as 125, n. 54. For an analysis of the early traditions on this incident, see Mohammed Shahab Ahmed, "The Satanic Verses Incident in the Memory of the Early Muslim Community: An Analysis of the Early Riwāyahs and their Isnāds" (Ph.D. thesis, Princeton University, 1999); Alan Jones, "The Real Satanic Verses?" The Arabist: Budapest Studies in Arabic 23 (2001): 125-33. For an analysis of the story in relation to Rushdie's novel, see Șādiq Jalāl al- ${ }^{c}$ Aẓm, Dhihniyyat al-tahrīm: Salmān Rushdī wahaqīqat al-adab (London \& Limassol: Riyāḍ al-Rayyis, 1992), 276-83. See also Ian Richard Netton, A Popular Dictionary of Islam (London: Humanities Press International, Inc., 1992), 226.

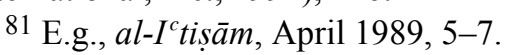

82 Serialized in al-Ahrām between 21 September and 25 December 1959. First published as a book in 1967 by Dār al-Ādāb in Beirut. The novel was 
condemned at the time on the pretext that it did not treat the sacred beliefs of Islam with the appropriate reverence. Consequently, the novel was never published in book form in Egypt. ${ }^{83}$ Among typical books published since the late 1980s in the Islamic world to defend Islam against Rushdie and Mahfūz, ${ }^{84}$ one opens with the following Qur ānic verse:

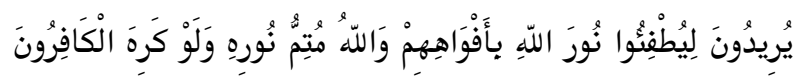

They desire to extinguish with their mouths the light of God; but God will perfect his light, though the unbelievers be averse. ${ }^{85}$

Inspired by remarks made by the late Syrian president Hāfiz alAsad, ${ }^{86}$ and convinced that Zionists were behind the publication of Rushdie's book, ${ }^{87}$ the writer $S \bar{a}^{\supset} i b{ }^{c} a^{c} \bar{u} d$ addresses Mahfüz with the following words: ${ }^{88}$

translated by Philip J. Stewart under the title Children of Gebelawi (London: Heinemann, 1981).

${ }^{83}$ Cf. Najīb Mahfūz, "al-Adab, al-hurriyya, al-thawra," Mawāqif 1 (OctoberNovember 1968): 85-86. On the novel and its various interpretations, see R. Snir, "The Arab-Israeli Conflict as Reflected in the Writing of Najīb Mahfūz,", Abr-Nahrain 27 (1989): 127; idem, "The 'World Upsidedown' in Modern Arabic Literature: New Literary Renditions of an Antique Religious Topos," Edebiyât n.s. 5,1 (Spring 1994): 51-75. On the religious objections and recent attacks on the banned novel, see Stagh 1993, 157-70. The argument that the novel was written "purely to curry favor with the Nasser regime in Egypt" (Ruthven 1990,123) is very odd, since scholars have accepted that Mahfūz's novel was intended to be mainly a manifest against ' $\mathrm{Abd}$ al-Nāṣir's regime (see Snir 1994, 61. Cf. Ghālī Shukrī's interpretation in Hazīn ' Umar, al-Mughtarib Ghālī Shukrī (Cairo: al-Hay a al-Miṣriyya al- ${ }^{\mathrm{c}} \mathrm{A} m m a$ li-l-Kitāb, 2000), 90-91).

${ }^{84}$ Similar books were written in various languages in addition to Arabic. For example, Iran's Ministry of Islamic guidance published in 1996 a book by Ahmad Zomorodian entitled "Who is The Satan," written according to its introduction, in order to expose "anti-Islamic propaganda" in Rushdie's novel and "stop spiteful nonsense from being spread against the pillars of our religion" (according to adabiyat@listhost.uchicag.edu [7 September 1996]).

$85 \mathrm{Al}$-Saff 8; translation according to Arthur J. Arberry, The Koran Interpreted (Oxford: Oxford University Press, 1979 [1964]), 581.

${ }^{86}$ E.g. Șā̄ib Sa ${ }^{\mathrm{u}} \overline{\mathrm{u}}$, al-Radd calā al-murtadd Salmān Rushdī shaytānn alșahāyina (Tripoli [Lebanon]: Jarrūs Press, 1991), 9, 37-38.

${ }^{87}$ Ibid., 40-42, 67-77.

88 Ibid., 77-78. 
Was it not enough for you to allude to and slander the son of the Alley? ${ }^{89} \ldots$ Islam is not a field of experiments for your literary projects ... its sanctities are not symbols of your vulgar desires and filthy tendencies. Islam is elevated human spirit and fragrant holy firebrands which your filthy bodies and spirits do not encompass, just as with the wicked [writer], the son of the damned, in his novel Laylat al-Qadr. He does not even know what Laylat al-Qadr means! ${ }^{90}$

Another book, by Nabīl al-Sammān, sums up the campaign against Rushdie and his supporters with the following call to Arab writers:

Arab writers are earnestly called upon to write about Arabs and Muslims in living international languages in a style that Westerners will understand, and to develop these Islamic and Arabic studies in their homelands based upon their own heritage, instead of on Orientalists' writings about Islam and Arabs, which they infused with their hostile desires and tendencies against everything that is Arabic and Muslim, beginning with the crusades and until the modern period. ${ }^{91}$

Wanting to show that among Westerners and Christian writers there are also other images of Islam, the Egyptian writer Sayyid Hāfiz Abū alFutūh (b. 1952), published, in 1989, a book entitled "They said about Islam: letters to Salman Rushdie from the greatest intellectuals and philosophers of the Christian world," which opens with the following Qurª̄nic verse:

$$
\text { وَأَمَّا الزَّبَدُ فَيَذْهَبْ جُفَاءً }
$$

As for the scum, it vanishes as jetsam. ${ }^{92}$

The book's first section presents sayings about Islam by such writers as Goethe (1749-1832), A. M. L. de Lamartine (1790-1869), Karl Marx (1818-83), G. B. Shaw (1856-1950) and Tolstoy (1828-1910). ${ }^{93}$ The second section presents sayings about Islam by Christian Arab writers such as Shiblī Shumayyil (1860-1917), Rashīd Salīm al-Khūrī (18871984), Mīkhāōîl Nu ${ }^{c}$ ayma (1889-1988) and Jūrjī Zaydān (1861-1914). ${ }^{94}$

\footnotetext{
${ }^{89}$ Writer's note: "an allusion to his novel $A b n \bar{a}^{\jmath}$ (sic!) häratinā."

90 Writer's note: "an allusion to the writer al-Ṭāhir ibn Jallūn."

91 Nabīl al-Sammān, Hamazāt shaytāniyya wa-Salmān Rushd̄̄ (Amman: Jam $^{c}$ iyyat $A^{\mathrm{c}}$ māl al-Mațābic ${ }^{\mathrm{a}}$ al-Ta ${ }^{\mathrm{c}}$ āwuniyya, 1989), 117.

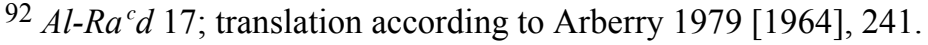

93 Sayyid Hāfiz Abū al-Futūh, Qālū can al-Islām: Rasā̄il ilā Salmān Rushdī min kibār mufakkirī wa-falāsifat al- ${ }^{c}$ àlam al-masīḥī (Cairo: Madbūlī, 1989), 23-139.

94 Ibid., 141-61.
} 
Another book, by Rif ${ }^{c}$ at Sayyid Ahmad, opens with the following Qurª̄nic verse:

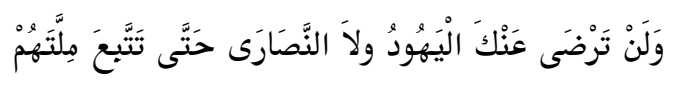

Never will the Jews be satisfied with thee, neither the Christians, not till thou followest their religion. ${ }^{95}$

In an appendix the author lists the names of "the most famous of Western Orientalists, the majority of whom offended Islam, did not understand Islamic civilization and distorted its various symbols." The more than 380 scholars are divided into seven sections according to their nationality-France, Germany, Italy, Spain, United Kingdom, USA, and USSR. ${ }^{96}$ As for the attitude of Muslim writers and intellectuals to Rushdie's novel, the author argues that "the reactions of the Muslim collective mind (which is comprised of the nation's writers, intellectuals and scholars) were varying between full rejection of the novel (this is the dominant characteristic of the reactions) and rejection with caution and reservations." ${ }^{97}$ However, he mentions three Muslim writers who supported Rushdie's novel "without any reservations," namely, Najīb Maḥfūz, Waḍ̣ạ̣̄ Sharāra from the Lebanese University, and Ḥamīd al-

95 Al-Baqara 120; translation according to Arberry 1979 [1964], 15.

${ }^{96} \mathrm{Rif}^{\mathrm{c}}$ at Sayyid Ahmad, Āyāt shaytāniyyya: Jadaliyyat al-sirīāc bayna alIslām wa-l-gharb (Cairo: al-Dār al-Sharqiyya, 1989), 187-93. For other books and articles attacking Rushdie, see Shams al-Dīn al-Fāsī, Ayyāt samāwiyya fì alradd 'alā kitāb Āyāt shayțanniyya (Cairo: Dār Māyū al-Wațaniyya li-l-Nashr, 1989); Sa ${ }^{c} \overline{1} d$ Ayyūb, Shayțān al-gharb: Salmān Rushdī al-rajul al-māriq (Cairo: Dār al-I tișām, 1989); Ahmmad Daydāt, Shaytāniyyat al-Āyāt alshaytāniyya wa-kayfa khadaca Salmān Rushdī al-gharb (Cairo: Dār al-Faḍīa,

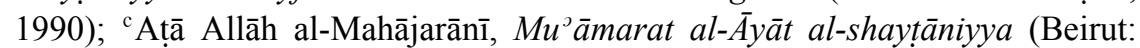
Dār al-Wasīla, 1993); "Abd al-Qādir Yūsuf, "Naqd li-riwāyat al-Āyāt alshaytāniyya li-Salmān Rushdī," in Fawwāz Manșūr, Dirāsāt fí al-ḥaḍāra alislämiyya wa-l-carabiyya (al-Ṭayba: n.p., 1999), 9-25. For one of the few books in Arabic which acknowledges the writer's right to create his own independent

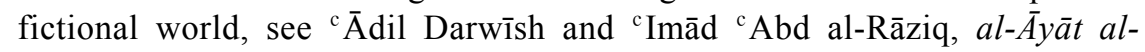
shaytāniyya bayna al-qalam wa-l-sayf (London: n.p., 1989). Ghālī Shukrī argues that most of the Muslim intellectuals who have attacked Rushdie never read the novel (al-Watan al- ${ }^{c} a r a b i ̄, 17$ March 1989, 22-27. Cf. al- ${ }^{\mathrm{c}}$ Aẓm 1992, 230).

97 Ahmad 1989, 150. 
Azrī. ${ }^{98}$ Alluding to Najīb Mahfūz's 1988 Nobel Prize for Literature, he describes the prize as "controlled by Jews who are hostile to Islam." Still, unlike most Islamist writers commenting on the Rushdie affair, the author presents Mahfūz's full outlook regarding Rushdie's novel, which, although supportive of Rushdie's right to free expression, does not agree with its content. ${ }^{99}$

Although he personally rejected any similarity between Awläd hăratina and The Satanic Verses, ${ }^{100}$ it was probably Maḥūẓ̌'s decision to denounce the death sentence pronounced against Rushdie that prompted radical Islamist circles to react. Following in the footsteps of Khumaynī, the blind Mufti of the radical Egyptian group al-Jihād, 'Umar ' Abd al-Rahmān (b. 1938), ${ }^{101}$ delivered in April 1989 a fatwā

98 Ahmad 1989, 174-75 (Hamīd al-Azrī, according to the author, became an apostate from Islam following the death sentence against Rushdie). For a full presentation of Sharāra's outlook, see Waḍ̣āh Sharāra, "Harb 'alā al-riwāya," in al- ${ }^{c}$ Unf al-uṣūlī: Muwājahāt al-sayf wa-l-qalam, 59-80.

99 Ahmad 1989, 174-75.

100 Al-Ahrām, 2 March 1989, 7. Cf. Mahfüz's interview in Der Spiegel, no. 9, 1989 (according to Appignanesi and Maitland 1990, 140-42); Samia Mehrez, "Respected Sir," in Naguib Mahfouz: From Regional Fame to Global Recognition, ed. Michael Beard and Adnan Haydar (Syracuse: Syracuse University Press, 1993), 67; Samia Mehrez, Egyptian Writers Between History and Fiction (Cairo: The American University in Cairo Press, 1994), 23-24. On the reaction of Islamist writers to Mah̆ūz's argument, see also al-Sammān 1989, 23. P. J. Stewart, who wrote the first thesis on the novel (P. J. Stewart, "Awlad Haretna: Its Value as Literature and the Public Reaction" [M.Litt. thesis, University of Oxford, 1963]) and published an English translation of it (Mahfouz 1981) argues that Mahfūz had been influenced by George Bernard Shaw's Back to Methuselah (Harmondsworth: Penguin Books, 1954). Based upon personal communication with Mậuzu in 1962, Stewart says that Mậfūz considered this play his favorite work by Shaw and that there are important similarities between the two works: each is a history of mankind in five parts, each includes the theme of immense longevity, and most important, both of them protest against the tyranny of a false God and contain a plea for the revival of true religion ( $\mathrm{P}$. J. Stewart, "An Arabic Nobodaddy: The Gebelawi of Naguib Mahfouz," in Arabicus Felix, Luminosus Britannicus: Essays in Honour of A. F. L. Beeston on his Eightieth Birthday, ed. Alan Jones (Reading: Ithaca Press, 1991), 21320).

101 On ${ }^{\mathrm{c}}$ Umar ${ }^{\mathrm{c}} \mathrm{Abd}$ al-Raḥmān, see The Oxford Encyclopedia of the Modern Islamic World, ed. J. L. Esposito (New York: Oxford University Press, 1995), 1: 10-11. 
calling for the death sentence against Mahfüz himself. ${ }^{102} \mathrm{He}$ argued that if such a fatwa $\bar{a}$ had been published when Maḥūz's Awläd häratinā had first come out, Rushdie would never have dared to publish his blasphemies. ${ }^{103}$ The fatwa $\bar{a}$ of ${ }^{\mathrm{c}} \mathrm{Umar}{ }^{\mathrm{c}} \mathrm{Abd}$ al-Rahmān is believed to be behind the assassination attempt against Mahfūz in Cairo on 14 October 1994. ${ }^{104}{ }^{\mathrm{c}}$ Umar ${ }^{\mathrm{c}} \mathrm{Abd}$ al-Rahmān, whose name has been associated with calls for violence and terrorism in the name of religion, left Egypt in 1990 and was able to take up residence in the United States, thanks to what American officials admitted were a series of administrative errors. In 1994 he was tried in Egypt in absentia, convicted and sentenced to seven years in prison. However, by then he was about to stand trial in New York on a twenty-count indictment for his role in the plot to blow up the United Nations and other New York monuments. ${ }^{105}$

Yet, in total contrast to the reactions in the late $1950 \mathrm{~s}$, following the outcry of the Islamist circles against Mahfūẓ's novel, 'Abd al-Rahmān's fatw $\bar{a}$ aroused many protests in the Arab world, ${ }^{106}$ as did Khumaynī's fatwa against Rushdie. Many of these protests were incorporated later in For Rushdie: Essays by Arab and Muslim Writers in Defense of Free Speech, ${ }^{107}$ among them the Syrian Adūnīs (b. 1930), the Palestinians Maḥmūd Darwīsh (b. 1941), Imīl Ḥabībī (1921-1996), Anton Shammās (b. 1950), and Liyāna Badr (b. 1952), the Saudi cAbd al-Rahmān Munīf (1933-2004), the Egyptian Șun ${ }^{c}$ Allāh Ibrāhīm (b. 1937), the Lebanese Hanān al-Shaykh (b. 1945) and Amin Maalouf (Amīn Maclūf) (b. 1949), and the Moroccans Mohamed Berrada (Muhammad Barrāda) (b. 1938) and Tahar Ben Jelloun (al-Ṭāhir ibn Jallūn) (b. 1944). Moreover, stating that no Muslim could be killed without a full and fair trial, Muhammad Sayyid Tantāīì, then the Grand Mufti of Egypt (and subsequently the

102 Al-Ahālī, 12 April 1989, 13.

103 Ruthven 1990, 116; Miller 1996, 53. In an interview with the New Yorker, 30 January 1995, 'Abd al-Rahmān denied that he had issued a fatwā, asserting that his comments had been misunderstood (according to Miller 1996, 481, n. 41).

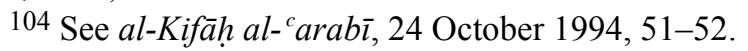

105 Miller 1996, 53.

106 E.g., al-Akhbār, 17 May 1989, 9; al-Wafd, 30 May 1989, 9; al-Ahālì, 7 June 1989, 11; al-Shirä ${ }^{c}$, 15 May 1989, 52; al-Hadaf, 9 April 1989, 40-43.

107 Translated by Kenneth Whitehead and Kelvin Anderson (New York: George Braziller, 1994). 
president of al-Azhar), rejected the fatwā against Mahfüz out of hand. ${ }^{108}$

Awlād hăratinā, as of this writing, has still not been published in Egypt in book form and does not appear on the lists of Mahfüz's works habitually given in the back of his books. ${ }^{109}$ It is significant to mention Judith Miller's observations, after meeting Maḥūz in early 1994:

Now the silence of intellectuals was not officially enforced; it was voluntary. Some intellectuals had been terrified into passivity. ... Even before Mahfouz was attacked, he had softened his own defense of fellow writer Salman Rushdie to avoid antagonizing the militants. ... Mahfouz had told me that Rushdie's work, which he said he had not read, was "very disturbing." Rushdie had "insulted Islam," and insults had "consequences." ... I was saddened by Mahfouz's retreat on such a critical principle of free expression. His revised position was not all that different from that of the Muslim brotherhood or, for that matter, from that of Sheikh Abdel Rahman in jail in New York. ${ }^{110}$

A good illustration of the way the Islamist literary discourse takes on the secular canonical center of the Arabic literary system as seen against the background of the Rushdie and Mahfūz affair is given by Șādiq Jalāl al- ${ }^{\mathrm{C}}$ Aẓm in his book Dhihniyyat al-tahrīm (The proscribing mentality) (1992):

Actually, if we lead Islamist logic to its utmost boundaries, it would be better if the Arab world had not known phenomena such as Țāhā Husayn or Tawfìq alḤakīm or Najīb Maḥfūz or Adūnīs or Khalīl Ḥāwī, since each of them represents a mode of intellectual and artistic expression which is imported from the West: criticism, theater, novel, and modern poetry. ${ }^{111}$

108 Al-Ahālī, 3 May 1989, 3; Ruthven 1990, 115-16.

109 On the connection between the Rushdie and Mahfüz affairs, see also Shukrī 1992, 307-346; Netton 1996. On the controversy surrounding Mahfūz's book, see also Muhammad Jalāl Kishk, Awlād hāratinā fìhā qawlān, Cairo: alZahrāō li-l-I'lām wa-l-Nashr, 1989.

110 Miller 1996, 71. On the other hand, we find Mahfūz saying on 3 June 1999: "It is absolutely inadmissible that a book or a painting be banned because it is supposedly base. If we were to start condemning works on moral grounds, we would be unable to stop. We can, at most, give our opinion: it is not our right to prevent others from doing the same" (Naguib Mahfouz, Naguib Mahfouz at Sidi Gaber: Reflections of a Nobel Laureate 1994-2001 [Cairo \& New York: The American University in Cairo Press, 2001], 71).

${ }^{111}$ Al- ${ }^{\mathrm{c}}$ Azm 1992, 82. In a note al- ${ }^{\mathrm{c}}$ Azmm quotes the Lebanese writer Ilyās Khūrī (b. 1948), in the Lebanese newspaper al-Safir (26 November 1990), accusing the Islamist groups of attempting to return, from the literary point of 
Al- ${ }^{\mathrm{C}}$ Azm's major argument is that all attacks against Rushdie have been based upon the assumption that literature, and art in general, must be submitted to Islamic concepts, that is, the literary discourse is not independent but has to remain within the limits of the religious discourse. Al'Azmm quotes a review, entitled "Nihilistic, Negative, Satanic," that Professor Syed Ali Ashraf, Director-General of the Islamic Academy in Cambridge, wrote about Rushdie's novel in which he typically asks such questions as "How could the two characters Gibreel (Gabriel) and Saladin fall from the sky and still be alive? How could they get transformed and how could they become normal again? How could they have the normal human body and how could they at the same time move about and influence people across space and time?"112

The clash between religious and secular discourses by no means entails that all advocates in either camp support the conclusions expected of them. Even religious notables are sometimes found to oppose the conclusions generally derived from the religious discourse. The collection of articles entitled al- ${ }^{c} U n f$ al-ușülì: Muwājahāt al-sayf wa-l-qalam (Fundamentalist violence: the clash of the sword and the pen) (1995) consists mainly of articles about the Rushdie affair by secular intellectuals denouncing the Islamist position regarding the affair. ${ }^{113}$ One article, by Muhammad Husayn Faḍl Allāh (b. 1935), the Lebanese Shiite spiritual

view, to the pre-modern genres, such as the qașìda, with al-Khalīl prosody. For a critical response to several of al- 'Aẓm's views, see Aḥmad Barqāwī, "Asīr alwahm," in al- ${ }^{\circ}$ Unf al-uṣūlī: Muwājahāt al-sayf wa-l-qalam, 81-114. For subsequent arguments by al- ${ }^{\mathrm{c}}$ Aẓm, see his $M \bar{a}$ bac da Dhihniyyat al-tahrīm: Qirā at al-Āyāt al-shaytāniyya, radd wa-tac $q \bar{\imath} b$ (Beyond the proscribing mentality: reading The Satanic Verses, reply and commentary) (London \& Limassol: Riyād al-Rayyis). The original title of the book, according to the author, was shorter, Qirä at al-Āyāt al-shaytāniyya, but the publisher changed it to the present title alluding to its relationship to the first book (Saqr Abū Fakhr, Sāadiq Jalāl al- ${ }^{c}$ Ažm: Hiwār bi-lā $\operatorname{dif} a \bar{f}$ [Beirut: al-Mu ${ }^{\circ}$ assasa al- ${ }^{\mathrm{c}}$ Arabiyya li-1-Dirāsāt wa-l-Nashr, 1998], 46), and indeed, the book includes articles written in reply to al-'Aẓm's Dhihniyyat al-tahrīm as well as his comments. For al- 'Azm's views on the topic, see also Abū Fakhr 1998, 67-78.

112 Al-' Azm 1992, 237-38. Ashraf's article was originally published in Impact International (London), 28 October-10 November 1988 and published again in Appignanesi and Maitland 1990, 18-21.

113 The book, published by Riyā al al-Rayyis in London, is a selection of articles that appeared after the outbreak of the Rushdie affair in the journal alNāqid (London). 
leader of Hizb Allāh (Party of God), entitled "Love of East and identity of Islam," is the sole contribution in a section entitled "Islamiyyūn ḍidda al-ta cṣ̣ub" (Islamists against fanaticism). Faḍl Allāh does not adopt the usual religious stance vis-à-vis Rusdhie ${ }^{114}$ and states that there is no topic that is not open to discussion, that Islamic history has been culturally diverse, and that "this diversity has made Islam a civilization and the Muslim a rich human being." 115 The collection opens with an article by ${ }^{\mathrm{c}} \mathrm{Azi \overline {z }}$ al- ${ }^{\mathrm{c}} \mathrm{Azmma}$ (Aziz al-Azmeh) entitled "Riwāya kāfira" (Novel of unbelief) attacking the Islamist view with respect to the Rushdie affair. ${ }^{116} \mathrm{Al}-^{-} \mathrm{Azma}$ ironically points out that the Islamist radicals base their attitude to the novel, "as they are accustomed to do," on the "formula" that "ignorance is a sign of piety." $117 \mathrm{He}$ concludes with the following lines:

The claim of the Islamists that they are speaking in the name of "the people" and that they are representing the majority is nothing but an imaginary expression of an indomitable political desire. The claim that Salman Rushdie and others that do not agree with the Islamists are rising against their history, nobility, and heritage and are propagandists for the West against Islam, is nothing but proof of the conflict the Islamists are living in, not with the West- since the Islamist political regimes are in harmony with it—but with modernity and progress in their own countries. We should emphasize that their illusion of totally representing the heritage, and their attempt to confiscate every important saying, point to a craze to confiscate the future in order to lay down foundations of comprehensive dictatorship in the name of a pure past devoid of any history.

114 See Muḥammad Husayn Faḍl Allāh, "Hawā al-sharq wa-huwiyyat alIslām," in al- 'Unf al-ușūlī: Muwājahāt al-sayf wa-l-qalam, 197-213. On Faḍl Allāh's outlook in that domain, see also Ahmad 1989, 166. On Faḍl Allāh's general conceptions, see Esposito 1995, 1: 453-56.

115 Faḍl Allāh 1995, 213

116 'Az̄̄z al- 'Aẓma, "Riwāya kāfira," in al- ${ }^{c}$ Unf al-uṣūlī: Muwājahāt al-sayf wa-l-qalam, 13-21. For a critical approach to al- 'Azma's article, see Anīs alJazāoirī, "Hadātha salafiyya!?" in al- 'Unf al-uṣūlī: Muwājahāt al-sayf wa-lqalam, 23-38. Al-Jazā̄irī rejects the analogy made by al- ${ }^{\mathrm{c}}$ Azma between The Satanic Verses and Awlād häratinā (35):

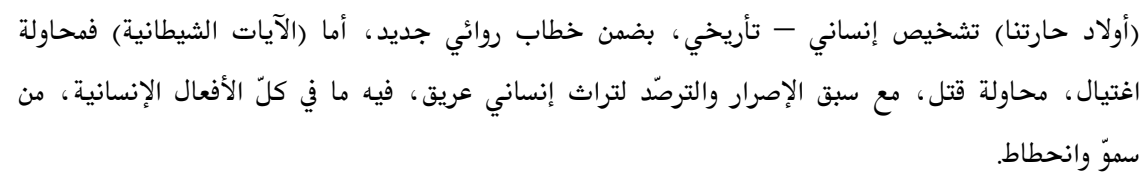

117 Al-c Aẓma, "Riwāya kāfira," 17. 
This is a program that anyone desiring any poor backward [form of] fascism could be proud of. ${ }^{118}$

Al- ${ }^{\mathrm{c}}$ Azma explains elsewhere that "in many third-world countries, The Satanic Verses is characterized as the work of a self-hater eager to ingratiate himself with the coloniser simply because the novel challenges the most conservative instincts of those groups claiming Muslim 'nativism." 119

The clash outlined in the foregoing between the Islamist and the modernist discourses illustrates that Arabic literature is still fettered by religious restrictions. In this respect, as we have seen above, there is no difference between the various genres. Thus, Homi K. Bhabha's reading of Rushdie's blasphemy, following Yunus Samad's analysis, ${ }^{120}$ seems to be without solid ground, at least not from the point of view of Arabic literature. Bhabha says:

It is the medium Rushdie uses to reinterpret the Koran that constitutes the crime. ... By casting his revisionary narrative in the form of the novel-largely unknown to traditional Islamic literature-Rushdie violates the poetic license granted to critics of the Islamic establishment. ... Rushdie's sin lies in opening up a space of discursive contestation that places the authority of the Koran within a perspective of historical and cultural relativism. It is not that the "content" of the Koran is directly disputed; rather, by revealing other enunciatory positions and possibilities within the framework of the Koranic reading, Rushdie performs the subversion of its authenticity through the act of cultural translation-he relocates the Koran's "intentionality" by repeating and reinscribing it in the locale of the novel of postwar cultural migrations and diasporas. ${ }^{121}$

118 Ibid., 21. Cf. al- ${ }^{\mathrm{c}}$ Azm 1992, 74-75. Cf. the argument of Riyād Najīb alRayyis (b. 1937) in Aktubu ilaykum bi-ghaḍab (London: Riyạ̄ al-Rayyis, 1996), 27-28:

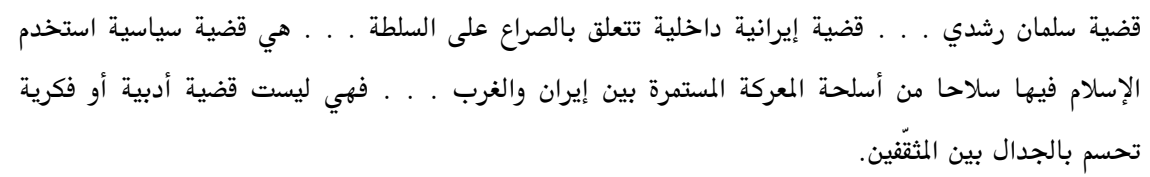

119 Aziz al-Azmeh, "The Satanic Flame," New Statesman and Society 20 (January 1989): 16-17. Cf. Brennan 1989, 145.

120 Y. Samad, "Book Burning and Race Relations: Political Mobilisation of Bradford Muslims," New Community 18, 4 (1991): 507-19.

${ }^{121}$ Homi K. Bhabha, The Location of Culture (London \& New York: 
If one should look at all for any generic differentiation, the matter touches on the popularity of the genre: the more popular the literary work, the stronger the demand to see it bound in traditional religious fetters. Thus, Darwīsh's poem cited above, "O My Father, I Am Yūsuf" had not provoked any public storm before Khaliffa sang it. The same could be said about Mahfüz's novel Children of Our Alley, the "danger" of which increased only in the light of the popularity of The Satanic Verses.

Nevertheless, especially from the view point of the intellectuals who expressed their unlimited support for Rushdie and Mahfüz, what happened in the 1980s is totally different from what happened 30 years before; and seems to be from another planet compared to the Arab literary arena of the 1920s. Significantly enough, the same change has occurred during the same period on the level of the literary texts themselves. Canonical Arabic literature has witnessed during the twentieth century a strong trend aiming at gradually separating it from its strict Islamic moorings in order to let it follow its course as secularized literature. ${ }^{122}$

\section{Linear versus Ironic Intertextuality}

In order to illustrate the nature of the "secularized" trend in Arabic literature and the revolutionary attitude to traditional religious and literary texts it introduced into the literary system, one can point to the dialectical cultural and poetic tension between the conceptions of the Egyptian poet and prose writer Muhammad Tawfìq al-Bakrī (1870-1932) and the Syrian poet Adūnīs (b. 1930), both of whom are Muslims. ${ }^{123}$ Considered to be pillars of Arabic literature, each of them in his own time, the short temporal span between them reveals the great changes that occurred in Arabic literature during the twentieth century.

Routledge, 1994), 226.

122 This trend, supported mainly by Arab writers and intellectuals living in the West, has been represented by avant-garde journals like Mawāqif (Paris \& Beirut) edited by Adūnīs (b. 1930) (1st issue: January-February 1969) and Farādīs (Cologne \& Paris) edited by ${ }^{\mathrm{c}} \mathrm{Abd}$ al-Qādir al-Janābī (b. 1944) (1st issue: July 1990). For an illustration of the main conceptions of this trend, see Nadīm al-Bīṭār (Baytạar), "Naḥwa calmana inqilābiyya," Mawāqif 2 (1969): 3450 .

123 The history of Arab literature has provided many examples that, although the Christian contributions were significant in changing literary norms, the actual changes took place only after the participation of Muslim writers in the reformist efforts (Shmuel Moreh, Modern Arabic Poetry 1800-1970 [Leiden: Brill, 1976], 57-58). 
Al-Bakrī was a typical representative of neoclassicist rhetorical Egyptian prose and the author of Sahārij $a l-l u^{\jmath} l u^{\nu}$ (The reservoirs of pearls), ${ }^{124}$ in which he said he had been striving to achieve the eloquence of al-Harīī (1054-1122) and the language of $\mathrm{Ru}^{\mathrm{b}} \mathrm{ba}$ b. al- ${ }^{\mathrm{c}} \mathrm{Ajj} \mathrm{j} \mathrm{j}$ (685762). This work, which is by no means religious, contains three travel impressions (two from France and one from Constantinople), an ode to solitude, a description of a ball in Vienna, a glorification of Saladin, and finally the announcement of the birth of the author's son. In his travel impressions, al-Bakrī tried his skills at imitating French poetic prosefor example, when describing the Bois de Boulogne and the battle of Austerlitz-but the result is full of allusions to Arabic proverbs and Arab history. Since he was especially fond of employing gharīb (rare words), frequent similes and classical poetic diction, sometimes even for romantic themes, the author's style is hardly reminiscent of the spirit of modern times. Al-Bakrī's poetry and prose were considered canonical by the literary establishment of his time. According to ${ }^{\mathrm{c}} \mathrm{Abbās}$ Maḥmūd al"Aqqād (1889-1964), his love poem "Dhāt al-Qawāfî" was the first to use $\operatorname{shi}^{c} r$ mursal (blank verse). ${ }^{125}$ Al-Bakrī was not only a distinguished poet from the very canonical center of the Arabic literary system, but also a religious notable who belonged to the Bakriyya Suufĩ brotherhood (tarīqa). He was later to be appointed Sheikh of this brotherhood, and he was likewise appointed to the leadership of all Sūfì brotherhoods (Mashyakhat al-Mash $\bar{a}^{\top} i k h$ ) and to that of the organization that registered the descendants of the Prophet (Niqābat al-Ashrāf). ${ }^{126}$

Significantly, since the 1950 s, no poet has been able to be simultaneously a central figure in the Arabic literary system and a traditional religious notable; literary modernism has not been able to live in harmony

\footnotetext{
124 See Muhammad Tawfīq al-Bakrī, Sahārīj al-lu’lu’ (Cairo: Mạ̣mūd Dajjāj al-Kutubī, 1907).

125 On al-Bakrī and his literary activities, see C. Brockelmann, Geschichte der arabischen Litteratur (Leiden: Brill, 1937-49), Suppl., 3: 81-82; ' Umar alDasūqī, F̄̄ al-adab al-ḥadīth (Cairo: Dār al-Fikr al- ${ }^{\mathrm{c}}$ Arab̄ì, 1959), 2: 401-436; 'Umar Riḍā Kaḥhāla, Mucjam al-mu’allifìn (Damascus: Matbac at al-Taraqqī, 1960), 9: 141; Moreh 1976, 130-33; Māhir Hasan Fahmī, Muhammad Tawfíq al-Bakrī (Kuwait: Dār al-Qalam, 1982); Brugman 1984, 80-82; Khayr al-Dīn al-Ziriklī, al- $A^{c} l \bar{a} m$ (Beirut: Dār al-' Ilm li-l-Malāyīn, 1984), 6: 65-66; Meisami and Starkey 1998, 1: 131.

126 Among al-Bakrī’s works is also Bayt al-Sidd̄̄q, in which he outlined his autobiography, as well as his religious and literary career (Bayt al-Siddīq [Cairo: Matba ${ }^{\mathrm{c}}$ at al-Mu' ${ }^{\mathrm{a}}$ ayyad, 1905], 11-26).
} 
with traditional religious concepts. The literary vision of Adūnīs differs radically from that of al-Bakrī, whose death two years after Adūnīs's birth represents metaphorically the revolutionary change in Arabic literature, which comes to differ in nature from the whole canonical Arabic literature of the first half of the twentieth century. The "Arabic-Islamic concept," as Adūnīs himself states in his comments on the poetry of Ahmad Shawqi (1868-1932), ${ }^{127}$ has been supplanted by a new concept that holds that Islam is not only a religion but also a literary and cultural heritage. ${ }^{128}$ Adūnīs sees two major trends in the 1950s in the field of Arabic poetic modernism, one stressing the national Arab identity of poetry and the other inspired by Marxist-Communism. There is, however, a third trend that reads the Arabic heritage in a different way, that is, to include not only pre-Islamic poetry, but also other cultures that have interacted with Arab culture, so that, for example, the Sumarian, Babylonian, and Canaanite cultures, are seen as part of the Arab cultural heritage:

${ }^{127}$ See Adūnīs, "Aḥmad Shawqī: Shā̄ir al-bayān al-awwal," Fuṣūl 3, 1 (October-December 1982): 18-22.

128 Adūnīs's conceptions are presented here only from the literary point of view. As to his world view, his opinions have gone through several stages since the late 1940s. Sādiq Jalāl al- ${ }^{\mathrm{c}}$ Aẓm refers to Adūn̄̄s in his last intellectual stage

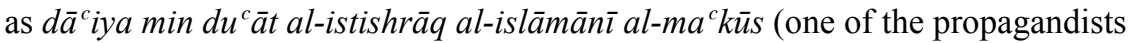
of reversed Islamist Orientalism) (al- ${ }^{c}$ Azm 1992, 67). This stage is illustrated, for example, in his arguments following the Islamic revolution in Iran in 1979 (e.g., Mawāqif 34 [Winter 1979]: 158), which contradict his outlook ten years before (e.g., Mawāqif 6 [October-December 1969]: 3). Adūnīs's new stage is summarized by al- ${ }^{\mathrm{c}}$ Aẓm as follows (al- $\left.{ }^{\mathrm{C}} \mathrm{Azm} 1992,71\right)$ :

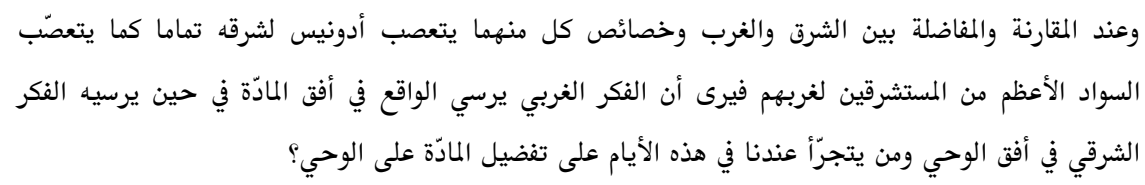

Al- ${ }^{\mathrm{c}}$ Aẓm also ridiculed Adūn̄̄s's frequent ideological transformations and mentions that his current rejection of nationalism, secularism, socialism, Marxism, communism and capitalism should be viewed against the background of his previous nationalism, secularism, Nasserist socialism and radical leftism (al${ }^{c}$ Azm 1992, 70). On the new intellectual stage of Adūn̄is and his "reversed Orientalism" against the background of Edward W. Said's Orientalism (London: Penguin, 1985 [1978] ), see Sadiq Jalal al-“Azm, "Orientalism and Orientalism in Reverse," Khamsin 8 (1981): 5-26; al- ${ }^{\mathrm{c} A z m}$ 1992, 49-85. 
According to this conception Arabism took on another dimension. It is not Arabism of race and nation, but Arabism of language and culture, in the sense that in linguistic and cultural Arabism all ancient heritages mingled together. In other words, this view considered the Arabic cultural poetic heritage not as a separate independent bloc, but a living continuity of a civilized heritage of about five thousand years. Hence, the Arabic language does not take its individuality and particularity only from its containing the whole of the pre-Islamic and Islamic heritage, but also from its richness and continuing capacity to revive and widen, that is, from its genius to absorb the ancient heritage that preceded it, and from its being the historical continuity of this heritage and its creative completion. 129

In order to illustrate this new concept of modernism, suffice it to compare the attitude towards the Qur ānic text of neoclassical poetry and the new poetry advocated by Adūnīs. Shawqī’s poem, "al-Jāmica alMișriyya" (The Egyptian University), ${ }^{130}$ recited during the inauguration of the University's institutions in 1931, includes a clear allusion to the Qurōan:

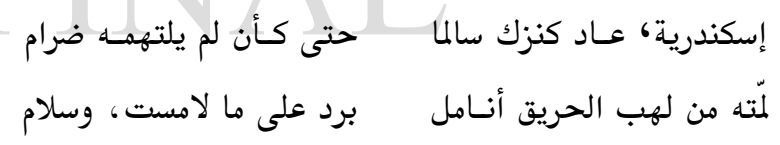

Alexandria, your treasure has returned safe, As if the fire never swallowed it up,

It was gathered from the flames by fingertips,

Coolness be with what they have touched, and safety.

These verses indicate that the city, which in antiquity had been one of the greatest cultural centers, is regaining its glory in modern Egypt. Mentioning the fire that is said to have destroyed Alexandria's Royal Library, Shawqī alludes to a Qur ${ }^{\circ}$ annic verse:

$$
\text { قُلْنَا : يَا نَارُ كُونِي بَرْدًا وَسَلامًا عَلَى إِبْرَاهِيمَ }
$$

129 Adūnīs 1993, 101-102. Jihād Fāḍil, who does not hide his disagreement with Adūnīs, distorts this conception when speaking of Adūnīs's attempt to "fragment Arab Islamic heritage and divide it into different 'heritages' (shardhamat al-turāth al- ${ }^{c}$ arabī al-islāmī wa-tafkīkuhu ilā turāthāt)" (al-Adab al-ḥadīth fì Lubnān: Naẓra mughāyira [London \& Beirut: Riyāḍ al-Rayyis, 1996], 334).

130 Al-Shawqiyyāt, (Cairo: n.p., n.d.), 4: 10-13. 
We said: "O fire, be coolness and safety for Abraham!"131

This allusion is considered to be entirely within the linear mode of intertextuality, ${ }^{132}$ that is, it draws on the Qur ānic image in full agreement with the religious discourse. That same discourse is totally rejected by Adūn̄̄s in his poem, "al-Mawt" (Death), subtitled "Thalāth marthiyāt ilā abī" (Three elegies for my father), from the collection Qașa $\bar{a}^{\curvearrowright} i d \bar{U} l \bar{a}$ (First poems) (1957). In the second elegy, he writes:

$$
\begin{aligned}
& \text { يا لهبب النار الذي ضمّه } \\
& \text { لا تلك بردا، لا ترفرف سلازْ } \\
& \text { في صدره النار التي كُورتت } \\
& \text { أرضا عبدناها وصيغت أنام. } \\
& \text { لم يفنَ بالنار ولكنّه } \\
& \text { عاد بها للمنشأ الأول } \\
& \text { للزمن المقبل } \\
& \text { كالشمس في خطورها الأول } \\
& \text { تأفل عن أجفاننا بغتةً }
\end{aligned}
$$

131 Al-Anbiy $\bar{a}^{\supset}$ 69; translation according to Arberry 1979 [1964]), 328.

132 Cf. Sasson Somekh, Genre and Language in Modern Arabic Literature, (Wiesbaden: Otto Harrassowitz, 1991), 53. See also this linear use in translated prose: Salīm Turkiyya (1999; cf.n. 63): 36, 245 (the original French appears in Nassib 1994, 34, 226). We find such intertextual linear allusion to the above Qur ${ }^{\circ} \bar{a}$ ic verse in poetry by non-Muslims, such as the Jewish Iraqi poet Shmuel Moreh (b. 1933) in his poem "Dahkat al-qadar" (The laugh of destiny) (alSharq, March 1972, 8; Shmuel Moreh, Tilka ayyām al-ṣibā (Jerusalem: Rābițat al-Jāmi ${ }^{c}$ iyyīn al-Yahūd al-Nāzihīn min al- ${ }^{\mathrm{I}}$ Irāq, 1998), 111-12). The Jewish writer Samīr Naqqāsh (1938-2004) in his novel Nzūla wa-Khayt al-Shaytān (Tenants and cobwebs) (Jerusalem: Rābitat al-Jāmic ${ }^{c}$ iyyīn al-Yahūd al-Nāzihīn min al- ${ }^{\mathrm{C}}$ Irāq, 1986) used the same allusion in an explicit sexual context (p. 21):

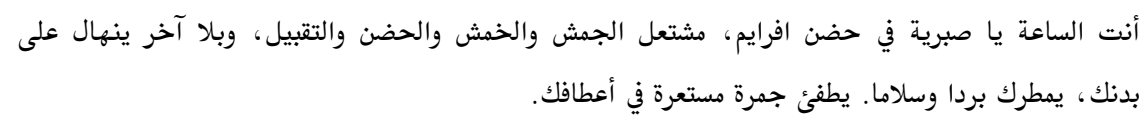

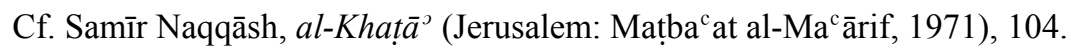




$$
\text { وهي وراء الأفق لم تأفلِ }
$$

O flames of the fire that embraced him

Do not be coolness, do not flutter safety

In his heart is the fire that was rolled up

Into a land we worshipped and that was shaped as men.

He did not die in the fire but

Took it back to the first source

To the coming time

As the sun in its first rising

Goes down suddenly from our eyelids

But over the horizon it has not gone down. ${ }^{133}$

The ironic mode of the intertextuality ${ }^{134}$ is evident: while God commands fire to "be coolness and safety for Abraham," Adūnīs demands the very opposite. Not only does the Qur ānic allusion function in a radically different way from what we find in the original, it might be seen as implying a sarcastic comment on it. ${ }^{135}$ Adūnīs here assumes the role of

133 Adūn̄is, al-A $A^{c}$ māl al-shic riyya al-kāmila (Beirut: Dār al- ${ }^{c}$ Awda, 1988), 1 : 39-40. This version of the elegy omits four lines of the first version (Adūnīs, $a l$ Āthār al-kāmila [Beirut: Dār al-' ${ }^{\mathrm{A}}$ Awda, 1971], 1: 117). On Adūnīs's attitude in the 1990s to the Qurª̄nic text, see Adūnīs, al-Nașs al-qur ${ }^{\circ} \bar{a} \bar{\imath} w a-\bar{a} f \bar{a} q$ alkitāba (Beirut: Dār al-Ādāb, 1993), 19-37. For the aesthetic justifications regarding the issue of the changing versions of his poems and his concept of "final version" (șigha nihā̄iyya), see Adūnīs 1988, 1: 5-7. Nevertheless, it goes without saying that several of his poems, especially from the early 1950s, were revised in subsequent editions since they reflected the Syrian ideology that he later abandoned. Adūnīs's first collection Qālat al-ard (The Earth says) (Damascus: al-Mațba ${ }^{c}$ a al-Hāshimiyya, 1954), for example, was changed in its subsequent editions to the point that it became "not revised poetry but new poetry" (Sharbal Dāghir, "Qālat al-Arḍ li-Adūnīs: Ayy zaman li-l-qașīda," al-Hayāt, 7 September 1996, 16). Dār al-Jadīd in Beirut described the new edition it published in 1996 of Qâlat al-ard, which is a faithful copy of the 1954 edition, as "pirated edition" (tab a muqarșana) since it appeared without Adūnīs's approval. See also Bās̄̄liyūs Hannā Bawārdī, "Bayna al-ṣaḥrāo wa-l-baḥr: Baḥth fī ta ${ }^{\top}$ thīr al-qawmiyyatayn al-lubnāniyya al-fīnīqiyya wa-l-sūriyya ${ }^{c}$ alā al-adab al'arabī al-mu āạsir" (M.A. thesis, University of Haifa, 1998), 180-211.

134 Cf. Somekh 1991, 61.

135 Cf. the following lines by al-Bayyātī from his poem "Qamar Shīrāz" from the collection bearing the same title (1979) (al-Bayyātī, Dìwān [Beirut: Dār al${ }^{\mathrm{c} A w d a, ~ 1979], ~ 517 ; ~ i d e m, ~ Q a m a r ~ S h i ̄ r a ̄ z ~[C a i r o: ~ a l-H a y ~ a ~ a ~ a l-M i s ̣ r i y y a ~ a l-~}$ c Āmma li-1-Kitāb, 1984], 105): 
the omnipotent almighty power who can guarantee eternal life for his dead father. This experience of being parallel to or one with God appears in many of Adūnīs' poems since the 1950s. In a poem entitled "Asrār" (Secrets), the poet says:

$$
\text { يضمَّنا الموت إلى صدره يحملنا سرّا على سرّه }
$$

Death embraces us

Risking His life, abstaining

Bearing us as a secret on His secret

Making from our plurality One. ${ }^{136}$

If, against this background, it is little wonder that radical religious circles consider Adūnīs to be a mulhid (heretic) or mukharrib (saboteur), ${ }^{137}$ interestingly, in contrast to other Muslim writers who in their writings deal with the Prophet, ${ }^{138}$ Adūnīs has never been under a death threat.

$$
\text { بدألأبير) للعشاق) ولحزني (لا تبردة) وأقول (اغتسلوا }
$$

136 Adūn̄̄s 1988, 1: 37. For the last line, compare Adūnīs's collection Mufrad bi-sigghat jam ${ }^{c}$ (Singular in the form of plural) (1975).

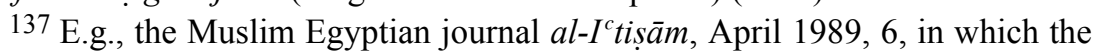
poet is described as al-muslim al-murtadd wa-l-mutanasssir (the Christianized apostate Muslim). When the Yemeni poet and scholar ${ }^{\mathrm{c}} \mathrm{Abd}$ al- ${ }^{\mathrm{c}} \mathrm{Azi \overline {z }}$ al-Maqālih (b. 1939) was considered as mulhid by a Saudi journal following the publication of one of his poems (al-Majalla al- ${ }^{c}$ arabiyya, 5,91 [May 1985], as quoted in Adūnīs, al-Nașs al-qur āañ̄, p. 191). Adūnīs wrote a few comments on the issue of poetry and blasphemy that can be considered as a defense on his part against the accusations leveled against him (Adūnīs, al-Naș al-qur'ānī, 183-90). For Adūnīs's views regarding the traditional Islamic framework of Arabic culture, see his introduction to Ahmad Shawqī, Dīwān al-nahḍ (Beirut: Dār al- ${ }^{c} \mathrm{Ilm}$ li1-Malāyīn, 1982), 5-19; Adūn̄̄s, "al-Sharc wa-1-shic r," Fuṣūl (Autumn 1992): 66-70; Adūn̄̄s 1993, 154-59.

${ }^{138}$ See above the cases of Salman Rushdie and Najīb Mahfūẓ. 
Timothy Brennan states that "there has traditionally been less tolerance towards attempts to humanize Muhammad or historicize the Quran than to attack God himself." 139 The outstanding example is the Urdu poem "Shikwah" (Complaint) by Muhammad Iqbāl (1875-1938), in which he accuses God of infidelity. He catalogues all that Muslims have done for God over the centuries, and points out that nevertheless God has neglected them and allowed the Muslim world to be destroyed. In one of the more startling passages of the poem, Iqbāl exclaims: "At times You have pleased us, at other times / (it is not to be said), You are a whore." 140 Iqbāl was angrily denounced as a blasphemer, but his life was never in danger.

Adūn̄is's new poetic vision has gradually penetrated into the center of the Arabic literary system. There is no better proof of this development than the sharp reactions to that vision from both marginal edges of the present literary system: on the one hand, the conservative, especially religious circles, who consider it as a heresy and a great danger; ${ }^{141}$ and on the other hand, the modernist circles who refer to Adūnīs's revolutionary vision not only as traditional but also as a "disgrace." 142 Still, his vision has never gained much popularity among the Arab masses, and Adūnīs himself, not to mention representatives of modernist circles opposing his vision, is mainly active in the West.

\section{Conclusion}

From the seventh century the activity in the Arabic literary system generally occurred within the borders defined by Islam, as well as by a cultural heritage that had become nearly as sacred as the religious laws, although Arabic literature was never wholly a religious one. ${ }^{143}$ Yet, most contemporary literary endeavors have carefully avoided any infringement of the basic Islamic conceptions. At the same time, the growing number of

139 Brennan 1989, 146.

140 Ibid., 143.

${ }^{141}$ E.g., Anwar al-Jundī, Matā ya $a^{c} \bar{u} d u$ al-adab al-mu āṣir ilā așālatihi (Cairo: Dār al-Anșār, .n.d.).

142 E.g., ' Abd al-Qādir al-Janābī, Risāla maftūḥa ilā Adūnīs (Paris: Manshūrāt Farādīs, 1994), published as the first work of a series entitled Faḍ al-s $\bar{a}^{\jmath} i d$ (The disgrace of the prevailing situation). Cf. also the above-mentioned journal Farādīs, as well as al-Laḩa al-shicriyya edited by Fawzī Karīm (b. 1945) (London, 1st issue, Summer 1992).

143 Cf. Ghālī Shukrī, Shi ${ }^{c}$ runā al-ḥadīth . . . ilā ayna? (Beirut: Dār al-Āfāq al-Jadīda, 1978 [1968]), 19. 
cases in which attempts at censorship have been challenged by human rights organizations and have produced protests from intellectuals throughout the Arab world and outside it is one of the indications that Arabic culture since the nineteenth century has been gradually detaching itself from subjection to the religious factor alone. In addition, contemporary Arabic literary output is no longer, as it was in medieval times, the production so-to-speak of an international cultural community. It has been gradually becoming again, as it was in the pre-Islamic period, a literature of the Arabs alone. In the Abbasid period, many of the central literary figures were of non-Arab descent, Persians being particularly numerous. From about the tenth century onwards, Muslim Persia began to replace Arabic with Persian as the predominant literary medium, a process that was continued elsewhere outside the Arabic speaking countries. Even in the nineteenth century and the beginning of the twentieth, Arab poets of non-Arab descent could become part of the center of the literary canon. ${ }^{144}$ Today the three major peoples of the Middle East, Arabs, Turks and Iranians, have become intellectually isolated from one another. Arabic is still taught as a classical and scriptural language in Iranian schools and it has also been reintroduced into Turkish religious seminaries, but in effect Cairo, Teheran and Istanbul are culturally very remote from each other. ${ }^{145}$ Moreover, although the literary production of Islamist circles in the Arab world is considered to be an integral part of the discourse that brings together also the Islamist Persian and Turkish literary writings, this discourse is by no means part of the contemporary literary canon.

Also worth mentioning are the minor, but sometimes important, exceptions of Christian and Jewish contributions to Arabic literature. ${ }^{146}$

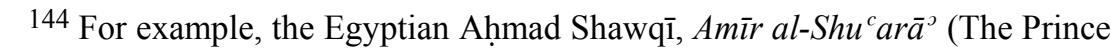
of Poets), was of Kurdish and Arab descent on his paternal side and of Turkish and Greek descent on his maternal side (cf. Brugman 1984, 35-36).

145 See Bernard Lewis, The Middle East and the West (London: Weidenfeld and Nicholson, 1968), 73. Cf. the rationale behind the study of Islamic popular literature and the literary relationship between the Arabs, Turks and Persians, as alluded to respectively in Husayn Mujīb al-Mișrī, $F \bar{\imath}$ al-adab al-shac $b \bar{\imath}$ al-islāmī al-muqāran (Cairo: al-Dār al-Thaqāfiyya li-l-Nashr, 2001), esp. 5-9, 229-40; idem, Șilāt bayna al- ${ }^{c}$ arab wa-l-furs wa-l-turk: Dirāsa ta ${ }^{3}$ rīkhiyya adabiyya (Cairo: al-Dār al-Thaqāfiyya li-l-Nashr, 2001), esp. 5-7; idem, Bayna al-adab al- ${ }^{c}$ arabī wa-l-turkī: Dirāsa fì al-adab al-islāmī al-muqāran (Cairo: al-Dār alThaqāfiyya li-1-Nashr, 2003), esp. 7-28.

146 On the contribution of Christian and Jewish poets to Arabic poetry after 
That the contribution of Christian Arab writers and intellectuals to modern literature in its formative stage in the nineteenth century and the beginning of the twentieth century was highly significant is not in any doubt. However, it is instructive to recall I. I. Krachkovskii's remark that the literary work of the Christian writer Nāșîf al-Yāzijī (1800-1871) was the first to violate the Muslim principal al- ${ }^{c}$ Arabiyya la tatanassaru (Arabic language cannot become Christian), which means that "Arabic literature cannot grant recognition to Christian writers."147 It also goes without saying that a contributory factor in the lead taken by Egypt in the Arab renaissance was the influx into that country, since the nineteenth century, of Christian Syrian men of letters, who pioneered free journalism and various cultural activities there. Christian Syrian writers also comprised the major nucleus of the intensive Arabic literary activities in the Mahjar, especially in North and South America. Still, Arab Christianity has never been disconnected from Arabic-Islamic social and cultural systems, and Christian writers in Arabic have never entered the canonical center of the literary system without adopting the ArabicIslamic literary heritage. ${ }^{148}$ It is interesting, especially against this background, that the writing of Arabic literature by Christians has never been

the rise of Islam, see Louis Cheikho, Shu ară al-nașāniyya $b a^{c} d a$ al-Islām (Beirut: Dār al-Mashriq, 1967); S. M. Stern, "Arabic Poems by Spanish-Hebrew Poets," in Romanica et occidentalia: Etudes dédiées à la mémoire de Hiram Peri (Pflaum), ed. M. Lazar (Jerusalem: Magnes Press, 1963), 254-63; R. Brann, "The Arabized Jews," in The Cambridge History of Arabic Literature: The Literature of al-Andalus, ed. M. R. Menocal, R. P. Scheindlin, and M. Sells (Cambridge: Cambridge University Press, 2000), 435-54.

${ }^{147}$ I. I. Krachkovskii, al-Riwāya al-ta ${ }^{\top}$ rìkhiyya fì al-adab al- ${ }^{c}$ arabī al-hadìth wa-dirāsāt ukhrāa (tr. ${ }^{\circ}$ Abd al-Rahị̄m al- ${ }^{c}$ Ațāwī) (Rabat: Dār al-Kalām li-l-Nashr wa-l-Tawzī' ${ }^{\mathrm{c}}$ 1989), 24. Cf. Ajami 1998, 42-43.

148 See the Christian writers mentioned in Hilary Kilpatrick, "Brockelmann, Kahhâla \& Co: Reference Works on the Arabic Literature of Early Ottoman Syria," Middle Eastern Literatures 7.1 (2004): 33-51. Kilpatrick shows, for example, how Carl Brockelmann omits in his GAL all texts by Jews and Christians intended only for their co-religionists: "Arabic literature is essentially Islamic" (ibid., 34). Cf. Ilyās Khūrī's statement in his introduction to a collection of articles dealing with the Arab Christians (al-Masīhiyyūn al- ${ }^{c} a r a b$ : Dirāsāt wa-munāqashāt [Beirut: $\mathrm{Mu}^{\mathrm{J}}$ assasat al-Abḥāth al- ${ }^{\mathrm{c}}$ Arabiyya, 1981], 9):

إن المسيحية العربية هي جزء عضوي من الواقع الاجتماعي والثقافي العربي والإسلامي، وهي بالتالي لا تستطيع

$$
\text { الانفصال عنه ، وإلا فقدت هويتتها وتميّزها. }
$$


totally confined to secular intellectuals who accept the Muslim framework of Arabic culture. Even today we find Christian religious notables who are engaged in composing traditional Arabic poetry. One outstanding example is the Coptic Patriarch of Alexandria, Shanūda the Third, who has written poems in the qașida form and even recited some in public gatherings. ${ }^{149}$ In any case, in contrast to the formative stage of modern Arabic literature, the number of Christian writers has become constantly fewer, and Christians were the first to adopt other languages as a new medium for literary creation.

The phenomenon of Arabic literary production by Jews was similarly rare under the rule of Islam. We know of the existence of Jewish poets writing in Arabic in pre-Islamic Arabia, but after the rise of Islam in the seventh century A.D. it was only during the era of Muslim rule in Spain that Jewish poets became well versed in literary Arabic and even won fame. ${ }^{150}$ One interesting phenomenon that can help shed light on the interaction between literature, ethnicity and religion is the short and marginal episode of Jewish-Arabic literary writing in the twentieth century, specifically, the production of Arabic belles-lettres by Jewish Iraqi writers beginning in the early $1920 \mathrm{~s}:{ }^{151}$ when this activity flowered in Iraq in the 1920s and 1930s, the authors showed obvious signs of Islamization. ${ }^{152}$

Contemporary Arabic literature by writers of other religions, such as

149 See al-Ahrām, 8 February 1994, 14.

150 On the linguistic situation in al-Andalus, see David J. Wasserstein, "The Language Situation in al-Andalus," in Studies on the Muwaššah and the Kharja, ed. Alan Jones and Richard Hitchcock (Reading: Ithaca Press, 1991), 1-15.

151 On the writing of Arabic literature by Jews, see R. Snir, "Cultural Changes as Reflected in Literature: The Beginning of the Arabic Short Story by Jewish Authors in Iraq" (Hebrew), Pe amim (1988): 108-29; idem, "We Were Like Those Who Dream': Iraqi-Jewish Writers in Israel in the 1950's," Prooftexts 11 (1991): 153-73; idem, “Arabic Literature of Iraqi Jews: The Dynamics of the Jewish Cultural System and the Relationship with the Arabic Cultural System” (Hebrew), Miqqedem Umiyyam 6 (1995): 255-88; idem, "“My Heart Beats with Love of the Arabs': Iraqi Jews Writing in Arabic in the Twentieth Century," Journal of Modern Jewish Studies 1,2 (2002): 182-203.

152 See R. Snir, "'Under the Patronage of Muhammad': Islamic Motifs in the Poetry of Jewish Writers from Iraq" (Hebrew), in Yetsirah ye-toladot bi-kehilot Yiśra el bi-Sefarad yeha-Mizrah (History and Creativity in the Sephardi and Oriental Jewish Communities), ed. Tamar Alexander et. al. (Jerusalem: Misgav Yerushalayim, 1994), 161-93. 
Druze $^{153}$ and Bahai authors, ${ }^{154}$ is also very minor and remains remote from the canonical literary center. Again, as we saw above, the religious constraints on the literary system by no means imply that Arabic literature is traditional or inclined towards religious themes. A poet or writer may exploit religious themes and at the same time attempt to break through the Islamic framework of Arabic literature, as we find, for example, in the Neo-Süfì trend in Arabic poetry. Unlike the marginal status of Islamist literature in the Arabic literary system, religious, and especially mystical motifs in secular literature are very popular. Authors dealing with such motifs and whose works are imbued with them are perceived to be an integral part of the canon. ${ }^{155}$

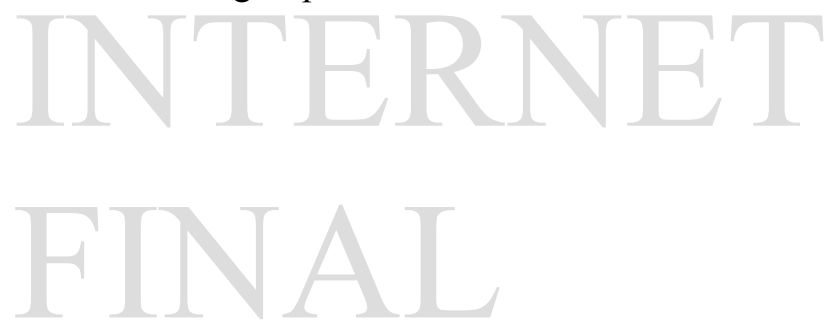

153 E.g., the Druze authors writing in Israel mentioned in Shmuel Moreh and Mạ̣mūd ' Abbāsī, Tarājim wa-āthār fì al-adab al- ${ }^{c}$ arabī fì Isrā̄ōl 1948-1986 (Shafā c Amrū: Dār al-Mashriq, 1987).

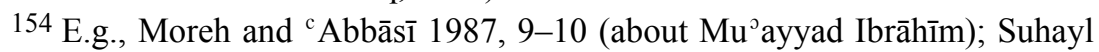

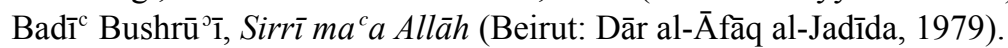

155 See R. Snir, "Human Existence According to Kafka and Șalāh cAbd alȘabūr," Jusūr 5 (1989): 31-43; idem, "A Study of Elegy for al-Hallāj by Adūn̄is," Journal of Arabic Literature 25,2 (1994): 245-56; idem, "Mysticism and Poetry in Arabic Literature," Orientalia suecana 43-44 (1994-95): 165-75; idem, Rak ${ }^{c} a t a \bar{n}$ fì al- ${ }^{c} i s h q$ : Dirāsa fì shic ${ }^{c}{ }^{c}$ Abd al-Wahhāb al-Bayyātī (Beirut: Dār al-Sāqī, 2002). 